Article

\title{
Orchard Floor Management Affects Tree Functionality, Productivity and Water Consumption of a Late Ripening Peach Orchard under Semi-Arid Conditions
}

\author{
Pasquale Losciale ${ }^{1, *(\mathbb{C})}$, Liliana Gaeta ${ }^{2}\left(\right.$ ) Luigi Manfrini $^{3}$, Luigi Tarricone ${ }^{4}$ and \\ Pasquale Campi ${ }^{2}$ (D) \\ 1 Department of Soil, Plant and Food Sciences-DiSSPA-, University of Bari “Aldo Moro”, 70126 Bari, Italy \\ 2 Research Centre for Agriculture and Environment, CREA-Council for Agricultural Research and Economics, \\ 70125 Bari, Italy; liliana.gaeta@crea.gov.it (L.G.); pasquale.campi@crea.gov.it (P.C.) \\ 3 Department of Agricultural and Food Sciences-DISTAL, Alma Mater Studiorum, University of Bologna, \\ 40126 Bologna, Italy; luigi.manfrini@unibo.it \\ 4 Research Centre for Viticulture and Enology, CREA-Council for Agricultural Research and Economics, \\ 70010 Turi, Italy; luigi.tarricone@crea.gov.it \\ * Correspondence: pasquale.losciale@uniba.it
}

Received: 23 October 2020; Accepted: 13 November 2020; Published: 17 November 2020

\begin{abstract}
Semi-arid conditions are favorable for the cultivation of late ripening peach cultivars; however, seasonal water scarcity and reduction in soil biological fertility, heightened by improper soil management, are jeopardizing this important sector. In the present two-year study, four soil managements were compared on a late ripening peach orchard: (i) completely tilled (control); (ii) mulched with reusable reflective plastic film; (iii) mulching with a Leguminosae cover-crop flattened after peach fruit set; (iv) completely tilled, supplying the water volumes of the plastic mulched treatment, supposed to be lower than the control. Comparison was performed for soil features, water use, tree functionality, fruit growth, fruit quality, yield and water productivity. Even receiving about $50 \%$ of the regular irrigation, reusable reflective mulching reduced water loss and soil carbon over mineralization, not affecting (sometimes increasing) net carbon assimilation, yield, and fruit size and increasing water productivity. The flattening technique should be refined in the last part of the season as in hot and dry areas with clay soils and low organic matter, soil cracking increased water evaporation predisposing the orchard at water stress. The development and implementation of appropriate soil management strategies could be pivotal for making peach production economically and environmentally sustainable.
\end{abstract}

Keywords: mulching; flattening; irrigation; photosynthesis; transpiration; soil quality; water stress integral; fruit growth; water use efficiency; productivity

\section{Introduction}

Fruit growing is a key sector for the Mediterranean economy, society and environment. It is the highest value among the agricultural productions, representing $17 \%$ of the total EU agricultural turnover (FAO-Food and Agriculture Organization of the United Nations, 2018). Furthermore, orchards contribute to land preservation via stewardship and climate regulation through evapotranspiration [1] and represent one of the most typical fruit crops of the Mediterranean Basin [2], thus being at the basis of both its economy and dietary culture.

Fruit growing has a double-faced nature. On one side, the great demand of high-quality products. The fruits, most of which are delivered to the fresh market, are asked to meet the consumer demand with very high-quality standards [3] as fruit consumption improves health and well-being [4]. This, at 
world level, makes the fruit sector very competitive, creating concerns and often pushing the fruit growers more on the yield than in quality production. Orchard intensification techniques are one of the results from this request. On the other side, society has expressed concern about the exploitation of agricultural inputs because of their dramatic impact on natural resources and ecosystem functioning [5].

Peach is among the most representative and valued fruit species in the Mediterranean Basin. The southern Italy environment is usually hot and dry until the beginning of autumn, therefore is particularly suitable for early and late ripening peach cultivars. However, late cultivars are more water demanding due to the long-lasting persistence of fruits on the plant [6].

Climate change and foreseeable future resource limitations (mainly water) threaten Mediterranean fruit production. The secure supply of high-quality fruit is under jeopardy because of increased heat and water stress conditions [7], reduced productive land [8], decreased soil fertility due to intensive management practices, reduced water availability and competition for water with other productive sectors and human activities [8]. In Mediterranean countries, the reduction in organic matter, which impacts soil fertility, is a common occurrence, for climatic reasons [9]. This is often aggravated by improper management of the residues of agricultural products, the low use of organic amendments and the rapid mineralization of the organic compounds due also to intensive tillage practices [10]. A multi-year life cycle assessment study showed that fertilizers and energy consumption (i.e., electricity, fossil fuel) and water were the main impact factors in peach cultivation [11]. Fertilizers and energy consumption are indeed indicated to be the most impactful on emissions and climatic disorders. Climate change, with its increased temperatures, can have negative effects on tree productivity if scheduling irrigation is not applied properly. However, agriculture is already the main user of water, consuming about $70 \%$ of freshwater, and it must achieve savings, rather than further increases, in its water needs [12]. Water scarcity can be tackled by improving water saving techniques. In particular the rational management of soil can increase water use efficiency either through decreasing soil evaporation, using artificial [13-15] or natural [16,17] mulching material, and increasing soil water holding capacity, via decompaction and organic matter enrichment. Recent experiences in horticultural crops $[18,19]$ reported that water and $\mathrm{N}$ recycling at agroecosystem level can be enhanced by cover crop practice and natural mulching covering techniques, independently from the soil management strategy. The authors pointed out that the improved nitrogen surplus was not sufficiently retained in the agroecosystem without cover crop. On the contrary, the practices adopted in the treatments with the cover crop or temporary intercropping considerably improved the N self-sufficiency of the system. Beneficial effects have been found in grapes [20,21]. Grape ecosystem services provided by Mediterranean vineyards are particularly threatened, because soil functions are often impaired by yearly repeated intensive agricultural practices or weed and pest management. The authors demonstrated that the potential of soil management practices to enhance soil functioning, can be promoted by the presence of a cover crop, even temporarily, in the inter row [20,21]. Moreover, Almagro found that improved soil management in rainfed Mediterranean agroecosystems can be a powerful strategy to mitigate the current atmospheric $\mathrm{CO}_{2}$ increase, through soil carbon sequestration and stabilization [22]. However, few publications on the effect of orchard floor modification on fruit trees, in general, and on peach tree development and functioning, including fruit production, in particular, are available [23]. These authors found that changed soil management practices such as zero tillage, supply of organic amendments, understory mowing, retention of crop residues, can result in worthwhile gains within a long-term period. In a Mediterranean peach orchard, these gains can include increased production and also increased sustainability with higher level of soil organic carbon and litter carbon pools [23]. However, to date, orchard soil and water management often rely only on grower and extension service experience or, in the most advanced cases, are driven by data on soil water content and/or climate conditions and plant status [24-26]. Real-time tree performance, as well as the inter-relation among the different chemical, physical and microbiological variables affecting soil fertility, is little considered. Solutions to the major threats encountered by the fruit production sector may be found through approaches that consider the soil-plant system as a whole and, therefore, address improving the entire orchard performance to 
cope with water scarcity and climate change $[27,28]$. Since orchards are particularly complex systems, different methods and approaches should be adopted under different, even contrasting, pedo-climatic, economic and social conditions [29]. Even lesser explored in horticulture, the use of different mulching material in the fruit orchard is deserving of particular interest. The use of plastic mulch was adopted with the aim of increasing the water use efficiency in a dryland rainfed area. However, the plastic adopted in the mulching was dark in color with negligible results on light diffusion and probably enhancing soil temperature $[30,31]$. Recent studies pointed out the positive effect of mulching with high-reflective biodegradable plastic film on productivity and water use efficiency on peach [15].

The aim of the present study was to investigate the effect of four different orchard floor managements on tree functionality, productivity and water consumption of a late ripening peach cultivar orchard under semi-arid conditions. The comparison was performed among the following treatments: (i) completely tilled, (ii) mulched with reusable and reflective plastic film, (iii) mulching with a Leguminosae cover crop flattened after peach fruit set, with the aim of increasing the organic matter and water holding soil capacity; (iv) completely tilled and reducing irrigation at the same volumes supplied to the plastic mulched treatment.

\section{Materials and Methods}

\subsection{Experimental Set-Up and Pedo-Climatic Conditions}

The trial was carried out in 2015 and 2016 at the Experimental farm of the Council for Agricultural Research and Economics (Research Centre for Agriculture and Environment), in southern Italy (Rutigliano, lat.: $40^{\circ} 59^{\prime} \mathrm{N}$, long.: $17^{\circ} 01^{\prime} \mathrm{E}$, alt.: $147 \mathrm{~m}$ asl) on 3-year-old peach (Prunus persica (L.) Batsch var. laevis) trees of a late ripening cultivar "Calred" [32] grafted on Missour rootstock, trained as slender spindle and spaced $4.0 \times 2.5 \mathrm{~m}$. The experimental site is under the Mediterranean climate, characterized by warm and dry summers. The average air temperature throughout the year and during the vegetative-reproductive season is 15.5 and $20^{\circ} \mathrm{C}$, respectively, and the annual rainfall is about $535 \mathrm{~mm}$, mainly concentrated in the autumn and late winter periods and usually greatly reduced, or absent, in the spring-summer period [33].

Four different orchard managements were tested: soil tilled (T); inter-row mulching with a reusable and machine-resistant reflective plastic film (C/820 Black Silver Orchard; thickness: $100 \mu \mathrm{m}$; Ginegar Plastic product Ltd., Ginegar, Israel) to reduce soil evaporation and to increase the diffuse light (M); inter-row mulching with horse bean (Vicia faba. L.) sown in November and flattened after peach fruit set forming a natural mulching on the soil (F). The last treatment (S) was established on tilled soil supplying the same irrigation volume of $\mathrm{M}$ that was supposed to be lower than the control $(\mathrm{T})$ as evaporation was limited by the plastic mulching. Since horse bean contributed to Nitrogen fixation, $N$ supply on F treatment was halved in comparison to T, M and S, while the Phosphorus and Potassium supply was increased by $25 \%$ in order to feed the service crop.

In order to verify the homogeneity of soil characteristics at the beginning of the trial, as well as to evaluate the evolution of the soil conditions as a function of the four treatments, three soil samples per treatment were collected at the beginning of the trial (before flattening period), after the harvest of the first year and at the end of the second year (just before the winter pruning). Soil was evaluated for its physico-chemical traits: soil texture by hydrometer method, total carbon organic content (TOC, $\%)$ by the dry-combustion procedure with a TOC Vario Select analyzer (Elementar, Germany), $\mathrm{pH}$, electric conductibility (EC, $\left.\mathrm{dS} \mathrm{m}^{-1}\right), \mathrm{N}$ ( $\mathrm{g} \mathrm{kg}^{-1}$, Kjeldahl procedure) and $\mathrm{P}$ ( $\mathrm{mg} \mathrm{kg}^{-1}$, Olsen method) content. Soil texture was similar among the four treatment and it was classified as clay loam [34]. Soil water content in volume at field capacity $(\mathrm{FC},-0.03 \mathrm{MPa})$ and wilting point $(\mathrm{WP},-1.5 \mathrm{MPa})$ were $0.34 \mathrm{~m}^{3} \mathrm{~m}^{-3}$ and $0.21 \mathrm{~m}^{3} \mathrm{~m}^{-3}$, respectively (measured using the Richards chambers). At $0.6 \mathrm{~m}$ of depth, the parent rock is present; this reduces the capacity of the root systems to expand beyond this layer. At the beginning of the trial also, the evaluated chemical trait results were not statistically different among the treatments (Table 1). 
Table 1. Soil chemical traits at the beginning of the trial (14 April 2015) after the harvest of the first year of the study (24 September 2015) and before the winter pruning of the second year (16 December 2016). Within each date and for each variable, different letters indicate a statistical difference at $p \leq 0.05$.

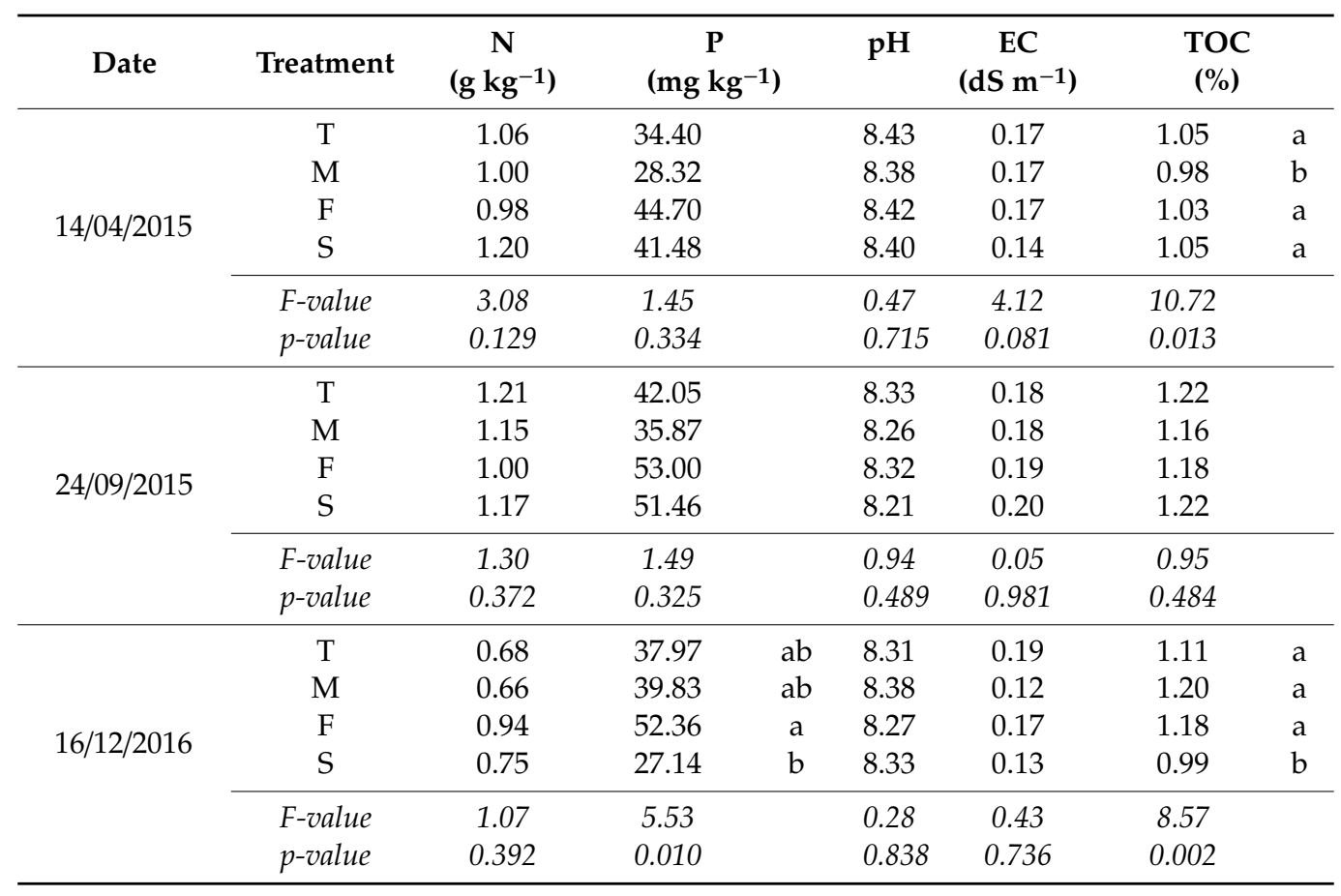

\subsection{Water Supply and Soil Water Content}

Water was supplied with drip irrigation system having 2 drippers per tree, and a flow rate of $81 \mathrm{~h}^{-1}$ per dripper. Volumetric soil water content (SWC) was measured by capacitive probes (10HS, Decagon Devices Inc., Pullman, WA, USA) linked to dataloggers (Grillobee, TecnoEL, Italy). For each treatment, three points were monitored. Capacitive probes were installed horizontally into the soil profile, on the row at $0.3 \mathrm{~m}$ from peach trees and at $-0.1,-0.3$ and $-0.5 \mathrm{~m}$ from the soil surface, in order to intercept the dynamics of soil water content below the dripping lines. For each treatment, water content in the whole soil profile was calculated averaging the values of the three depts in each of the three points. Probes were previously calibrated in order to measure the volumetric soil water content (SWC) and identify the intervention threshold (IT). The IT corresponded to the SWC at which the readily available water was completely used. The IT of $0.26 \mathrm{~m}^{3} \mathrm{~m}^{-3}$ was adopted; this value was obtained considering a depletion fraction (fraction of available soil water that can be depleted from the root zone before moisture stress) of 0.5 [35]. When the IT was reached, the amount of water necessary to return at FC was supplied [36]. T, M and F were irrigated monitoring the SWC while $S$ received the same water volume of $\mathrm{M}$.

\subsection{Leaf Functionality and Tree Water Relations}

Three plants similar in canopy size and potential crop load were selected for each treatment. At fruit cell division, pit hardening, fruit cell expansion and close to the harvest stages, leaf net photosynthesis $\left(\mathrm{Pn}, \mu \mathrm{mol} \mathrm{m} \mathrm{m}^{-2} \mathrm{~s}^{-1}\right)$, stomatal conductance $\left(\mathrm{gs}, \mathrm{mol} \mathrm{m}^{-2} \mathrm{~s}^{-1}\right)$ and transpiration $\left(\mathrm{Tr}, \mathrm{mol} \mathrm{m}^{-2} \mathrm{~s}^{-1}\right.$ ) were measured on well-exposed leaves placed on the east and west side of the canopy, 4 times during the day (9.00-17.00 h), with an open circuit infrared gas analyzer fitted with an LED light source (Li-COR 6400XT, LI-COR, Lincoln, Nebraska, USA). At each time of the day and canopy side, light intensity was maintained constant across the 4 treatments, setting the LED light source at the natural irradiance experienced by the leaf immediately before the measurement. The values obtained on the west and east side of the canopy were averaged for each tree. At the same time of measure, stem water potential 
( $\Psi \mathrm{s}, \mathrm{MPa}$ ) was measured on the same trees belonging to the 4 treatments according to [37]. Pn and $\mathrm{Tr}$, collected during the day, were integrated [38], providing the specific amount of $\mathrm{CO}_{2}\left(\Sigma \mathrm{Pn}, \mathrm{mol} \mathrm{m}^{-2}\right)$ and water $\left(\Sigma T r, \mathrm{~mol} \mathrm{~m}^{-2}\right)$ fixed and transpired by a square meter of leaf during the time of measure. To take into account the amount of energy used by trees to raise water from the soil during the time of measure, the water stress integral $\left(\mathrm{S}_{\Psi}, \mathrm{GPa}\right)$ was calculated as the difference between the integral by time of stem water potential and the integral by time of the minimum stem water potential measured in the same time range $[39,40]$.

\subsection{Fruit Growth and Productivity}

The fruit growth pattern was monitored during the season by means of a digital caliper implemented with a datalogger able to store the data (HK-Horticultural Knowledge s.r.l. Bologna, Italy) on twelve fruit per tree. The fruit volume $\left(\mathrm{V}, \mathrm{cm}^{3}\right)$ and the absolute growth rate (AGR, $\mathrm{cm}^{3}$ day $^{-1}$ ) were calculated assuming the shape of the peach as a spheroid and measuring the three axes of each peach [15].

At harvest (ready for hand selection: when fruit flesh firmness was around $3-5 \mathrm{~kg} \mathrm{~cm}^{-2}$ ), the number of fruits per tree (NF), the average fruit weight $(\mathrm{FW}, \mathrm{g})$, the yield $\left(\mathrm{Y}, \mathrm{tha}^{-1}\right)$ and the irrigation water productivity (WPi, $\mathrm{kg}$ ) of fresh fruit per cubic meter supplied with irrigation [41] were evaluated on the same trees monitored for fruit growth and leaf functionality. The total soluble solids content (TSS, ${ }^{\circ}$ Brix), flesh firmness (FF, $\mathrm{kg} \mathrm{cm}^{-2}$ ) and the percentage of fruit skin red overcolor (RC, \%) were measured on 10 fruit per tree.

\subsection{Statystical Analysis}

For each period of measure soil data, $\Sigma \mathrm{Pn}$ and $\Sigma$ Tr were subjected to ANOVA. Fruit growth data (V and AGR) used for the statistical analysis were obtained averaging the measures taken on each tree. A by-time repeated ANOVA was performed analyzing separately the data of fruit cell division, pit hardening, fruit cell expansion and ripening stages, respectively. Three productivity, water use efficiency and fruit quality variables were tested by means of an ANCOVA considering the number of fruits as the covariate variable.

\section{Results}

\subsection{Pedo-Climatic Conditions}

The two-year study's thermic patterns during the experiment period (1 June-10 September) were almost comparable with an average minimum, maximum and average temperature of about 20.6, 29.5 and $25.0^{\circ} \mathrm{C}$, respectively. The year 2015 was less rainy than 2016 with a cumulative rainfall during the period of $126 \mathrm{~mm}$. The year 2016 showed a cumulative rainfall of $206 \mathrm{~mm}$ till 31 August and an additional $147 \mathrm{~mm}$ of rain fallen in the first fortnight of September (Figure 1).

Soil measurements were performed on 14 April 2015, 24 September 2015 and 16 December 2016, before peach's full bloom, after the harvest and before the winter pruning of the second season, respectively. At the beginning of the trial, the soil chemical traits evaluated resulted in being not statistically different among the four treatments (Table 1). N, P, pH, conductibility and total organic carbon content were about $1.0 \mathrm{~g} \mathrm{~kg}^{-1}, 37.2 \mathrm{mg} \mathrm{kg}^{-1}, 8.4,0.16 \mathrm{dS} \mathrm{m}^{-1}$ and $1.0 \mathrm{~g} \mathrm{~kg}^{-1}$, respectively. After the first harvest, the treatments continued to be similar for soil chemical traits. At the end of the two-year trial, $\mathrm{S}$ showed the lowest value of $\mathrm{P}$ and TOC while the highest $\mathrm{P}$ content was recorded for $\mathrm{F}$, followed by $\mathrm{T}$ and $\mathrm{M}$ (Table 1).

\subsection{Water Supply and Soil Water Content}

In order to have all the treatments at the same soil moisture conditions at the beginning of the experiment, three and two full irrigations were provided regardless of the treatments in 18 May, 29 May and 5 June in 2015, as well as in 6 June and 14 June, in 2016. In 2015, the seasonal water 
supply was $1557 \mathrm{~m}^{3} \mathrm{ha}^{-1}$ for $\mathrm{T}$ and $\mathrm{F}$, and $815 \mathrm{~m}^{3} \mathrm{ha}^{-1}$ for M, S. The irrigation season lasted about 4 months (Figure 2A). In 2016, T and F received $1810 \mathrm{~m}^{3} \mathrm{ha}^{-1}$ while M and S $1023 \mathrm{~m}^{3} \mathrm{ha}^{-1}$ and the duration of the irrigation season was about 3 months (Figure 2B). M and S received about $50 \%$ less water than $\mathrm{T}$ and $\mathrm{F}$ in both years. Soil water content remained between the field capacity (FC) and the intervention threshold (IT) till the end of July in T, M and F during the two seasons. In the same period, S showed SWC lower than IT for several days (Figure 3, June-July). From the beginning of the irrigation season till the end of July, M and F showed the highest SWC values (average SWC of 0.32 and $0.33 \mathrm{~m}^{3} \mathrm{~m}^{-3}$ in 2015 and 2016, respectively, for $\mathrm{M} ; 0.31$ and $0.32 \mathrm{~m}^{3} \mathrm{~m}^{-3}$ for F). In the same period, T revealed SWC similar to M and F, in 2015 (average of $0.31 \mathrm{~m}^{3} \mathrm{~m}^{-3}$ ), while in 2016, it decreased at an average value of $0.29 \mathrm{~m}^{3} \mathrm{~m}^{-3}$. The average SWC of $S$ in the same period was 0.29 and $0.26 \mathrm{~m}^{3} \mathrm{~m}^{-3}$ in 2015 and 2016, respectively (Figure 3). Due to local watershed restrictions occurring during the period August-September for both the years, the irrigation frequency (number of peaks in Figure 3) was reduced for all the treatments. In this period, the SWC of T, F and S fell below the intervention threshold several times and in $\mathrm{S}$ it reached the wilting point; $\mathrm{M}$ showed the highest soil water content, rarely below IT (Figure 3). In this period, the comparison between $\mathrm{T}$ and $\mathrm{F}$, receiving almost the same water volume in each irrigation, showed that in August-September, after water supply SWC declined faster in $\mathrm{F}$ than in $\mathrm{T}$, reaching values lower than $\mathrm{T}$ and close to WP at the end of the irrigation season (Figure 3).
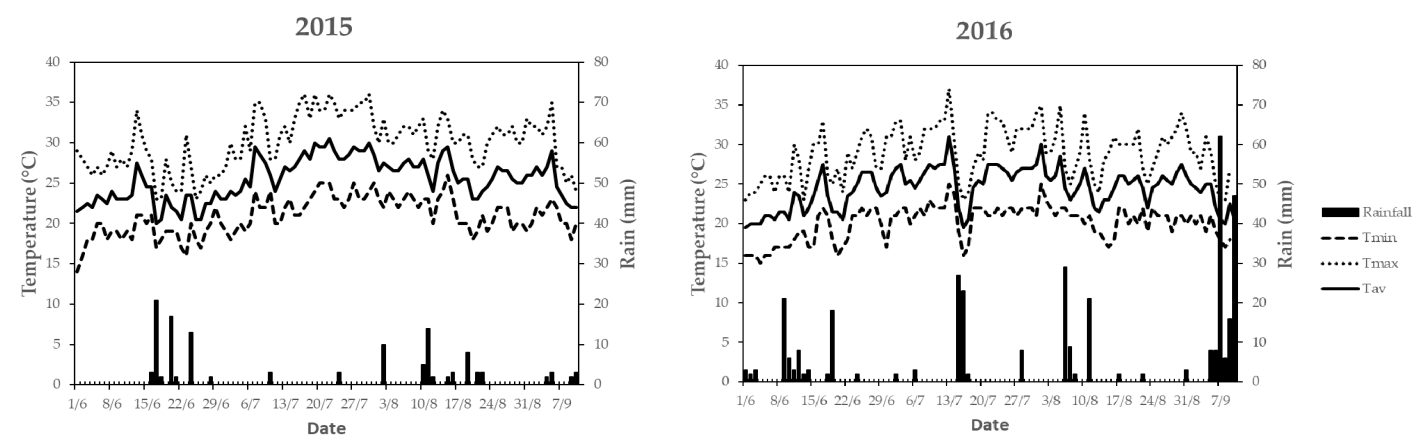

Figure 1. Air temperature (lines) and rainfall (bars) recorded for the peach orchard under investigation during the two years of study.
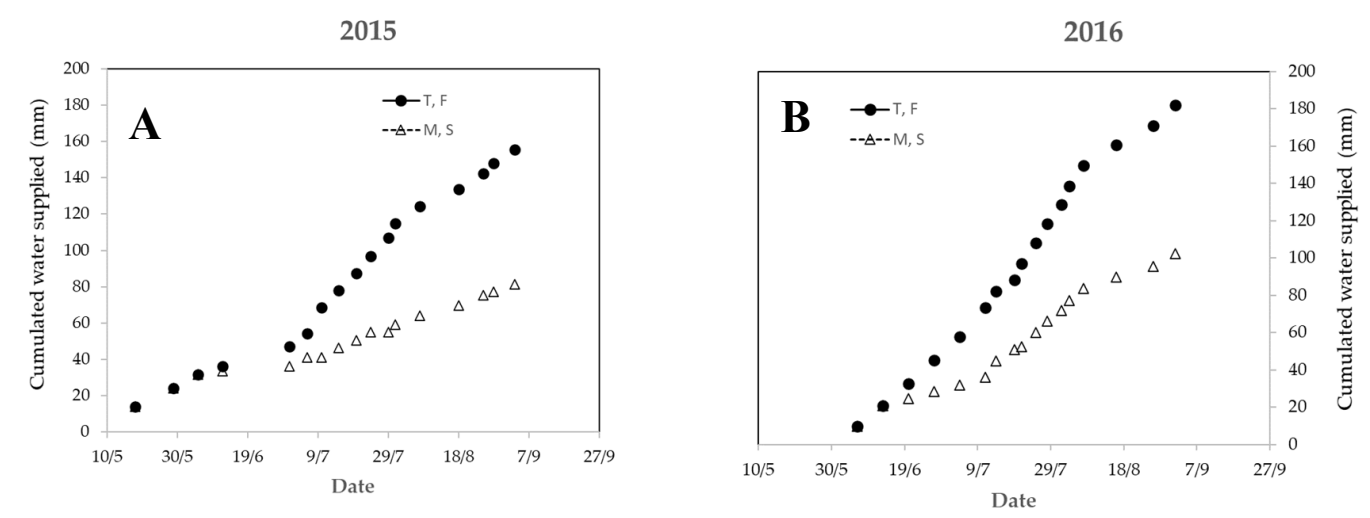

Figure 2. Cumulated water volumes supplied to T, F (closed circles) and to M, S (open triangles) recorded in 2015 (A) and 2016 (B).

\subsection{Leaf Functionality and Tree Water Relations}

Full bloom occurred on 7 April and 14 March in 2015 and 2016, respectively. Leaf gas exchange and stem water potential measures were performed $55,86,87,88$ and 120 days after full bloom (DAFB) in 2015 (1/6, 2/7, 3/7, 4/7 and 5/8), and 92, 107, 120, 135, and 163 DAFB (14/6, 29/6 12/7, 27/7 and 24/8) in 2016. 


\section{5}

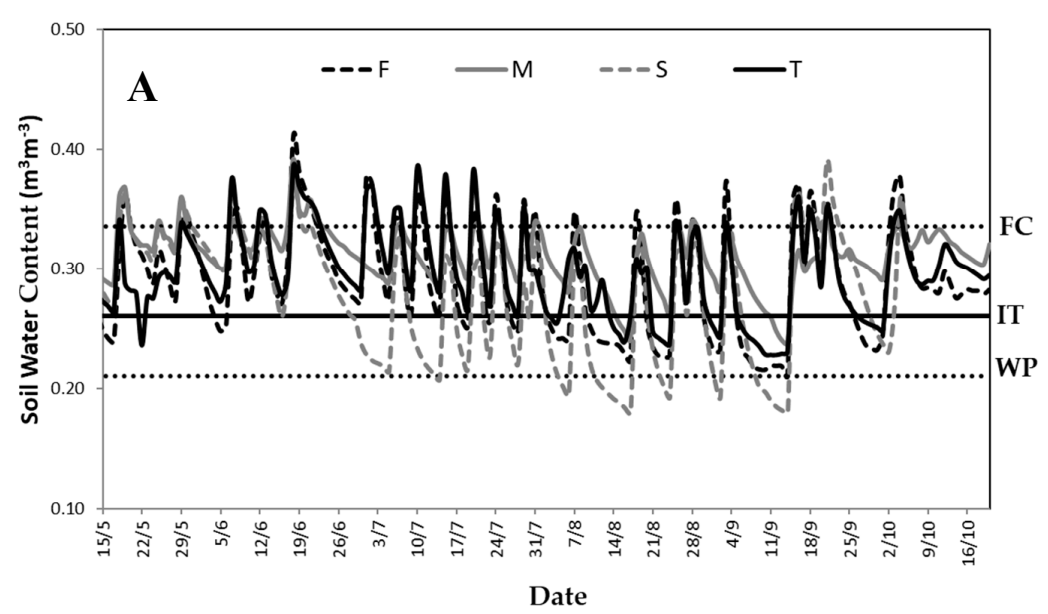

2016

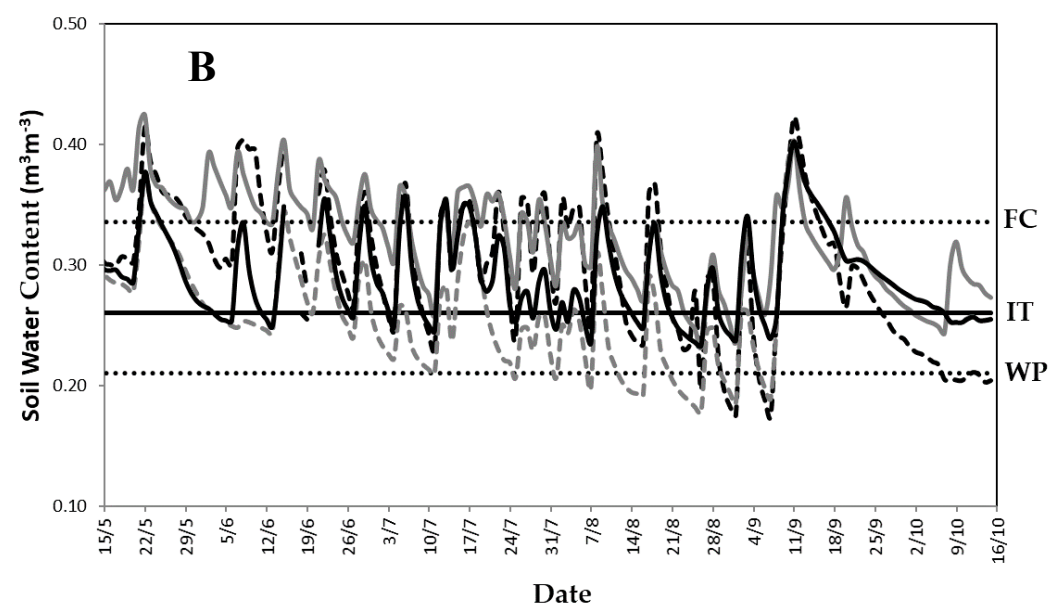

Figure 3. Soil water content $\left(\mathrm{m}^{3} \mathrm{~m}^{-3}\right)$ pattern recorded on the 4 treatments in 2015 (A) and 2016 (B). Horizontal dotted and continuous lines represent the field capacity (FC), the wilting point (WP) and the intervention threshold (IT), respectively.

\subsubsection{Season 2015}

At 55 DAFB, when water supply differentiation was not established yet, cumulative photoassimilation $(\Sigma \mathrm{Pn})$, transpiration $(\Sigma \mathrm{Tr})$ and the integral water stress $\left(\mathrm{S}_{\Psi}\right)$ were similar among the four treatments (Figure 4; Table S1). The average air temperature $\left(\mathrm{T}_{\text {air }}\right)$ and vapor pressure deficit $(\mathrm{VPD})$ during the measure period (9:00-17:00) were $29.9^{\circ} \mathrm{C}$ and $2.3 \mathrm{kPa}$, respectively; the midday stem water potential was around $-0.9 \mathrm{MPa}$ and the average stomatal conductance was about $0.164 \mathrm{~mol} \mathrm{~m}^{-2} \mathrm{~s}^{-1}$. At 86-87 and $88 \mathrm{DAFB}$, trees were at the end of the pit hardening stage and water supply was differentiated among the four treatments. At $86 \mathrm{DAFB}$, the average VPD and air temperature were $3.5 \mathrm{kPa}$ and $36.4^{\circ} \mathrm{C}$, respectively. A slight reduction in $\Sigma \mathrm{Pn}$ and $\Sigma \operatorname{Tr}$ were observed in $\mathrm{S}$, while the water stress integral $S_{\Psi}$ was statistically lower in $\mathrm{S}$ and $\mathrm{F}$ in comparison with $\mathrm{T}$ and $\mathrm{M}$ (Figure 4; Table S1). The midday stem water potential was around -1.2 MPa in $\mathrm{M}$ and $\mathrm{T}$ and $-1.5 \mathrm{MPa}$ in $\mathrm{F}$ and $\mathrm{S}$. The average gs recorded during the measure period was about $0.102 \mathrm{~mol} \mathrm{~m}^{-2} \mathrm{~s}^{-1}$ for M and T, $0.094 \mathrm{~mol} \mathrm{~m}^{-2} \mathrm{~s}^{-1}$ for $\mathrm{F}$ and $0.085 \mathrm{~mol} \mathrm{~m}^{-2} \mathrm{~s}^{-1}$ for S. At $87 \mathrm{DAFB}$, the average VPD was about $4.5 \mathrm{kPa}$ and the air temperature recorded during the time of measure was about $37.5^{\circ} \mathrm{C}$. S showed the cumulative photoassimilation and transpiration to be lower than the remaining treatments ( 0.142 and $72.5 \mathrm{~mol} \mathrm{~m}^{-2}$, respectively). The highest $\mathrm{S}_{\Psi}$ was recorded in $\mathrm{M}(-3.6 \mathrm{GPa})$, followed by $\mathrm{T}(-7.0 \mathrm{GPa}) ; \mathrm{F}$ and $\mathrm{S}$ showed the lowest 
values of the water stress integral of about $-10 \mathrm{GPa}$ (Figure 4; Table S1). The midday stem water potential was $-1.1,-1.25,-1.3$ and $-1.4 \mathrm{MPa}$ in $\mathrm{M}, \mathrm{T}, \mathrm{F}$ and $\mathrm{S}$, respectively, while the average gs was around $0.105 \mathrm{~mol} \mathrm{~m}^{-2} \mathrm{~s}^{-1}$ in M, T, F and $0.064 \mathrm{~mol} \mathrm{~m}^{-2} \mathrm{~s}^{-1}$ in S. At 88 DAFB, the average VPD and the air temperature of the period of measure (9:00-17:00) were $3.8 \mathrm{kPa}$ and $37.1^{\circ} \mathrm{C}$, respectively. The highest cumulative photoassimilation was recorded on $\mathrm{M}\left(0.25 \mathrm{~mol} \mathrm{~m}^{-2}\right)$, followed by $\mathrm{T}$ and $\mathrm{F}(0.198$ and $0.188 \mathrm{~mol} \mathrm{~m}^{-2}$, respectively). $S$ revealed the lowest $\Sigma \mathrm{Pn}\left(0.125 \mathrm{~mol} \mathrm{~m}^{-2}\right)$ and the same trend was observed for the cumulative transpiration (Figure 4A,B; Table S1). The average gs recorded during the period was $0.134 \mathrm{~mol} \mathrm{~m}^{-2} \mathrm{~s}^{-1}$ for $\mathrm{M}$ followed by $\mathrm{T}$ and $\mathrm{F}$, with an average gs of about $0.096 \mathrm{~mol} \mathrm{~m}^{-2} \mathrm{~s}^{-1}$ and $\mathrm{S}\left(\mathrm{gs}, 0.057 \mathrm{~mol} \mathrm{~m}^{-2} \mathrm{~s}^{-1}\right)$. M had the highest $\mathrm{S}_{\Psi}(-2.5 \mathrm{GPa})$ followed by $\mathrm{T}(-6.7 \mathrm{GPa})$; the lowest $\mathrm{S}_{\Psi}$ values were recorded in $\mathrm{F}$ and $\mathrm{S}$ with values of -14.2 and $-17.2 \mathrm{GPa}$, respectively (Figure $4 \mathrm{C}$ ). At 120 DAFB, trees were in the full fruit cell expansion stage. The average (9:00-17:00) air temperature and VPD were $33.5^{\circ} \mathrm{C}$ and $2.5 \mathrm{kPa}$, respectively. The lowest $\Sigma \mathrm{Pn}$ and $\Sigma \operatorname{Tr}$ were recorded in $\mathrm{S}(0.166$ and $48.6 \mathrm{~mol} \mathrm{~m}^{-2}$, respectively) while the remaining treatments were similar (Figure 4A,B; Table S1). The same trend was observed for $S_{\Psi}$ reaching the lowest levels of the season (Figure 4C; Table S1). The midday stem water potential was $-1.4,-1.5,-1.6$ and $-1.8 \mathrm{MPa}$ for M, T, F and S, respectively, and the average stomatal conductance recorded within the measure period (9:00-17:00) was around $0.106 \mathrm{~mol}$ $\mathrm{m}^{-2} \mathrm{~s}^{-1}$ for $\mathrm{M}, \mathrm{T}, \mathrm{F}$, and $0.066 \mathrm{~mol} \mathrm{~m}^{-2} \mathrm{~s}^{-1}$ for $\mathrm{S}$.

\subsubsection{Season 2016}

At 92 DAFB, when water supply was the same for all the treatments, no differences were recorded in terms of cumulative photoassimilation, transpiration and water stress integral; the average VPD and air temperature during the period of measure (9:00-17:00) were about $2.0 \mathrm{kPa}$ and $29.4^{\circ} \mathrm{C}$, respectively; the midday stem water potential was $-0.6 \mathrm{MPa}$ and the average gs was about $0.182 \mathrm{~mol} \mathrm{~m}^{-2} \mathrm{~s}^{-1}$. At pit hardening (107 DAFB), $\Sigma \mathrm{Pn}, \Sigma \operatorname{Tr}$ and $\mathrm{S}_{\Psi}$ were similar among the treatments (Figure 5; Table S1). Average air temperature and VPD were $29.6^{\circ} \mathrm{C}$ and $2.4 \mathrm{kPa}$, respectively; the midday stem water potential was $-0.8 \mathrm{MPa}$ and the average gs was $0.115 \mathrm{~mol} \mathrm{~m}^{-2} \mathrm{~s}^{-1}$. At the beginning of fruit cell expansion (12 July, $124 \mathrm{DAFB}$ ), the average VPD was about $4.5 \mathrm{kPa}$ and air temperature $37.6^{\circ} \mathrm{C}$. $\mathrm{T}$ and F showed the highest $\Sigma \mathrm{Pn}$ (around $\left.0.23 \mathrm{~mol} \mathrm{~m}^{-2}\right)$, while the lowest one was recorded on $\mathrm{S}(\sim 0.15 \mathrm{~mol}$ $\mathrm{m}^{-2}$ ). M revealed an intermediate $\Sigma \mathrm{Pn}$ of $0.18 \mathrm{~mol} \mathrm{~m}^{-2}$ (Figure 5A; Table S1). The highest cumulative transpiration was recorded on $\mathrm{F}\left(146.1 \mathrm{~mol} \mathrm{~m}^{-2}\right)$, followed by $\mathrm{T}\left(127.0 \mathrm{~mol} \mathrm{~m}^{-2}\right)$; the lowest $\Sigma \operatorname{Tr}$ was observed in $\mathrm{M}$ and $\mathrm{S}$ with an average cumulative transpiration of $89.8 \mathrm{~mol} \mathrm{~m}^{-2}$ (Figure $5 \mathrm{~B}$ ). The average gs during the period of measure was about $0.107 \mathrm{~mol} \mathrm{~m}^{-2} \mathrm{~s}^{-1}$ for $\mathrm{T}$ and $\mathrm{F}$ and $0.073 \mathrm{~mol} \mathrm{~m}^{-2} \mathrm{~s}^{-1}$ for $\mathrm{M}$ and $\mathrm{S}$. F and $\mathrm{T}$ had a quite similar water stress integral (-3.9 GPa), higher than $\mathrm{S}_{\Psi}$ recorded in $\mathrm{S}$ and $\mathrm{M}$ of about $-12 \mathrm{GPa}$ (Figure $5 \mathrm{C}$ ). The midday stem water potential was $-1.0 \mathrm{MPa}$ for $\mathrm{T}$ and $\mathrm{F}$, and $-1.3 \mathrm{MPa}$ for $\mathrm{S}$ and $\mathrm{M}$. At the fruit cell expansion stage (135 DAFB), the average air temperature and vapor pressure deficit recorded during the period of measure were about $32.5^{\circ} \mathrm{C}$ and $2.8 \mathrm{kPa}$, respectively. $\mathrm{M}$ and $\mathrm{F}$ showed $\Sigma \mathrm{Pn}$ and $\Sigma \mathrm{Tr}$ higher than T and S (Figure 5A,B; Table S1). The average gs recorded from 9:00 to 17:00 was about $0.118 \mathrm{~mol} \mathrm{~m}^{-2} \mathrm{~s}^{-1}$ in $\mathrm{M}$ and $\mathrm{F}$, and $0.098 \mathrm{~mol} \mathrm{~m}^{-2} \mathrm{~s}^{-1}$ in T and $\mathrm{S}$. The water stress integral was $-7.8 \mathrm{GPa}$ in $\mathrm{T}$, followed by $\mathrm{M}(-10.6 \mathrm{GPa}) ; \mathrm{S}$ and $\mathrm{R}$ had the lowest $\mathrm{S}_{\Psi}$ of about $-14.8 \mathrm{GPa}$ (Figure 5C; Table S1). The midday stem water potential at 135 DAFB was about $-1.0 \mathrm{MPa}$ in $\mathrm{T},-1.1 \mathrm{MPa}$ in $\mathrm{M}$ and $-1.3 \mathrm{MPa}$ in $\mathrm{F}$ and $\mathrm{S}$. Close to the harvest (163 DAFB), the average $\mathrm{T}_{\text {air }}$ and VPD were $29.1{ }^{\circ} \mathrm{C}$ and $1.9 \mathrm{kPa}$, respectively. $\mathrm{M}$ showed a cumulative net photoassimilation and transpiration higher than $\mathrm{T}$ and $\mathrm{S}$ and the lowest values were observed in F (Figure 5A,B; Table S1). The average stomatal conductance followed the same trend with gs of $0.126 \mathrm{~mol} \mathrm{~m}^{-2} \mathrm{~s}^{-1}$ in $\mathrm{M}$, about $0.099 \mathrm{~mol} \mathrm{~m}^{-2} \mathrm{~s}^{-1}$ in T and S, and $0.064 \mathrm{~mol} \mathrm{~m}^{-2} \mathrm{~s}^{-1}$ in $\mathrm{F}$. $\mathrm{S}_{\Psi}$ in M was $-4.4 \mathrm{GPa}$, higher than $\mathrm{T}$ and $\mathrm{S}$ ( -9.0 GPa); the lowest water stress integral was observed in $\mathrm{F}$ with $\mathrm{S}_{\Psi}$ of $-13.4 \mathrm{GPa}$ (Figure 5C). The midday stem water potential followed the same trend with values of $-1.4,-1.6,-1.6$ and $-1.8 \mathrm{MPa}$ recorded in $\mathrm{M}, \mathrm{T}, \mathrm{S}$ and $\mathrm{F}$, respectively. 

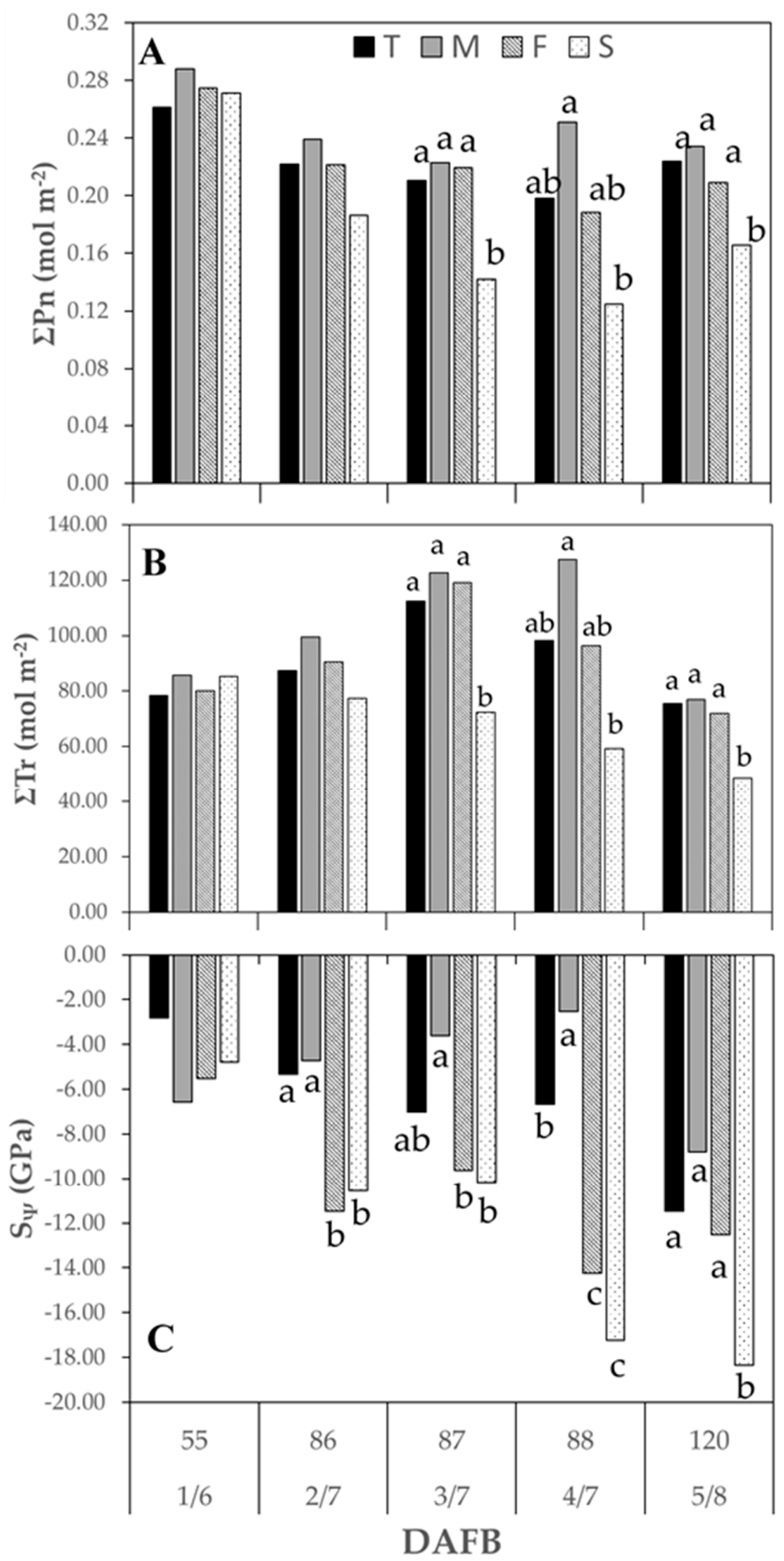

Figure 4. Cumulative leaf net photosynthesis $(\Sigma \mathrm{Pn})(\mathbf{A})$, transpiration $(\Sigma \mathrm{Tr})(\mathbf{B})$ and water stress integral $\left(\mathrm{S}_{\Psi}\right)(\mathbf{C})$ calculated for T (black bars), M (grey bars), F (dashed bars) and S (dotted bars) during the time of measure (9:00-17:00 h) of each day of measurement in 2015. Within the same date different letters indicate a statistical difference at $p \leq 0.05$. 


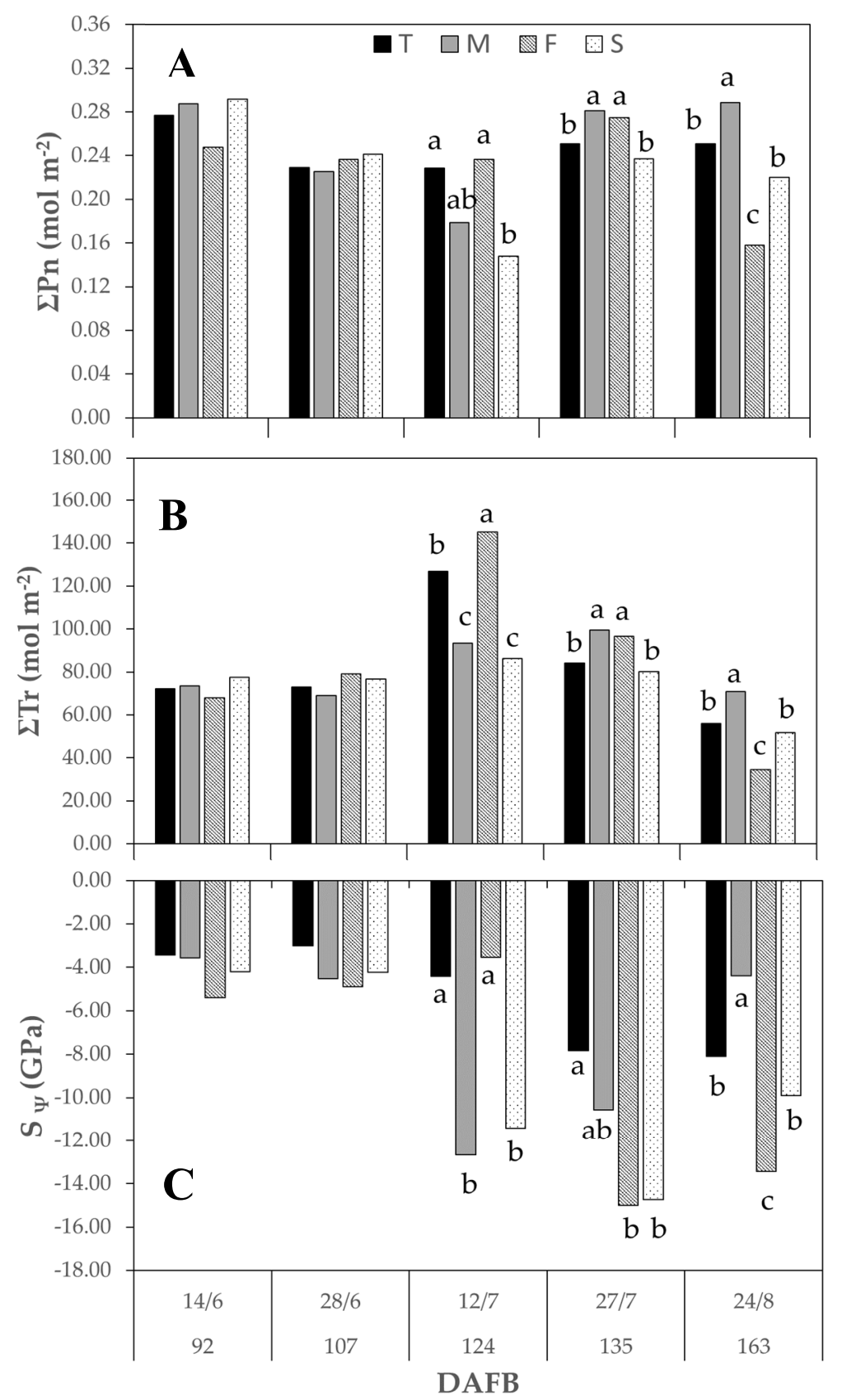

Figure 5. Cumulative leaf net photosynthesis $(\Sigma P n)(A)$, transpiration $(\Sigma T r)(B)$ and water stress integral $\left(\mathrm{S}_{\Psi}\right)(\mathrm{C})$ calculated for T (black bars), M (grey bars), F (dashed bars) and S (dotted bars) during the time of measure (9:00-17:00 h) of each day of measurement in 2016. Within the same date different letters indicate a statistical difference at $p \leq 0.05$.

\subsection{Fruit Growth and Productivity}

\subsubsection{Season 2015}

At the end of the fruit cell division stage (38-77 DAFB), no differences for fruit volume were recorded among the four treatments while the average AGR values observed in $\mathrm{M}$ and $\mathrm{S}$ were lower than those measured on T and F (Table 2; Figure 6). During the pit hardening stage (77-105 DAFB), the fruit volume was similar among the treatments (Table 2), and the absolute growth rate was higher in $\mathrm{T}, \mathrm{M}$ and $\mathrm{F}\left(\sim 0.59 \mathrm{~cm}^{3}\right.$ day $\left.^{-1}\right)$ than in S with an AGR value of $0.43 \mathrm{~cm}^{3}$ day $^{-1}$ (Table 2). The reduced AGR in $S$ was observed starting from 94 DAFB (Figure 6B). In the full fruit cell expansion stage 
(105-125 DAFB), T, M and F continued to have fruits bigger than S (Table 2) with a difference between S and the remaining treatments growing progressively (Figure 6A). The average AGR recorded between 105 and 125 DAFB was higher in M, T and F $\left(\sim 1.07 \mathrm{~cm}^{3}\right.$ day $\left.^{-1}\right)$ than in S with an AGR of $0.73 \mathrm{~cm}^{3}$ day $^{-1}$ (Table 2). F maintained an AGR similar to $\mathrm{M}$ and T till $115 \mathrm{DAFB}$; afterwards it decreased, reaching values closer to $\mathrm{S}$ (Figure 6B). During the last days before the harvest (125-148 DAFB), M and T showed an average fruit volume $\left(\sim 105.8 \mathrm{~cm}^{3}\right)$ higher than $\mathrm{F}$ and $\mathrm{S}$ with a value of about $88 \mathrm{~cm}^{3}$ (Table 2). The same behavior was observed for the absolute growth rate with values of about $2.34 \mathrm{~cm}^{3}$ day $^{-1}$, for M and $\mathrm{T}$ and $1.86 \mathrm{~cm}^{3}$ day $^{-1}$ for $\mathrm{S}$ and $\mathrm{F}$ (Table 2).
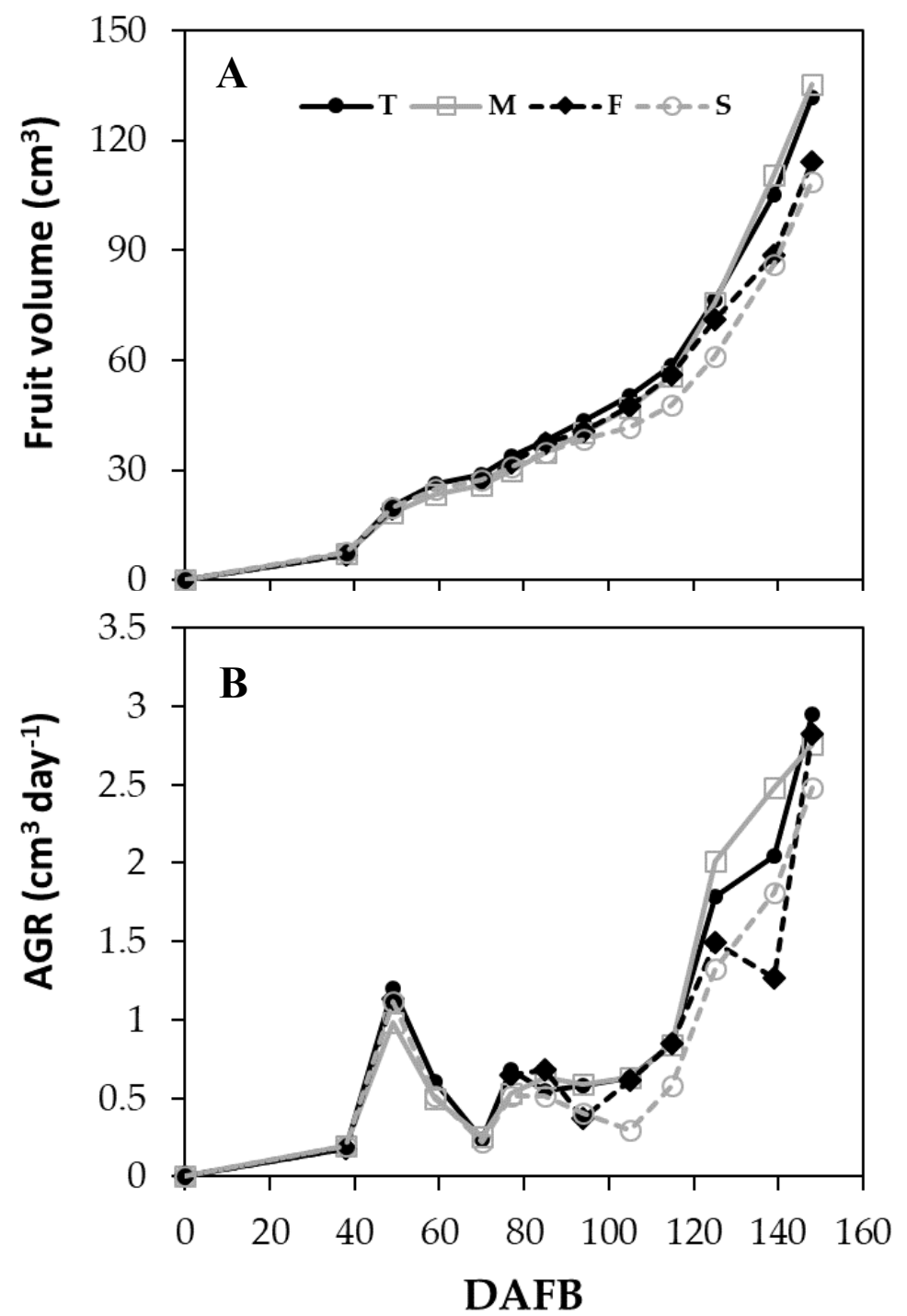

Figure 6. Fruit growth (A) and absolute growth rate (B) pattern recorded in 2015 for T, M, F and $\mathrm{S}$ treatments. 
Table 2. Average fruit volume (V) and absolute growth rate (AGR) recorded for T, M, F and S treatments in different fruit growth stages (Days After Full Bloom range, DAFB Range), in 2015. Within each stage, a by-time repeated ANOVA was performed. For each variable, different letters indicate a statistical difference at $p \leq 0.05$.

\begin{tabular}{|c|c|c|c|c|c|}
\hline DAFB Range & Treatment & \multirow{2}{*}{$\frac{\begin{array}{c}\mathbf{V} \\
\left(\mathrm{cm}^{3}\right)\end{array}}{23.18}$} & & \multicolumn{2}{|c|}{$\begin{array}{c}\text { AGR } \\
\left(\mathrm{cm}^{3} \mathrm{day}^{-1}\right)\end{array}$} \\
\hline \multirow{6}{*}{$38-77$} & $\mathrm{~T}$ & & & 0.58 & $\mathrm{~b}$ \\
\hline & M & 20.93 & & 0.49 & c \\
\hline & $\mathrm{F}$ & 21.46 & & 0.65 & a \\
\hline & S & 21.00 & & 0.51 & C \\
\hline & F-value & 3.14 & & 5.25 & \\
\hline & p-value & 0.108 & & 0.041 & \\
\hline \multirow{6}{*}{ 77-105 } & $\mathrm{T}$ & 41.35 & & 0.61 & $\mathrm{a}$ \\
\hline & M & 37.95 & & 0.60 & $\mathrm{a}$ \\
\hline & $\mathrm{F}$ & 39.42 & & 0.58 & a \\
\hline & S & 36.56 & & 0.43 & $\mathrm{~b}$ \\
\hline & F-value & 3.56 & & 5.83 & \\
\hline & p-value & 0.088 & & 0.033 & \\
\hline \multirow{6}{*}{$105-125$} & $\mathrm{~T}$ & 61.77 & a & 1.09 & $\mathrm{a}$ \\
\hline & M & 59.42 & a & 1.16 & $\mathrm{a}$ \\
\hline & $\mathrm{F}$ & 58.13 & a & 0.98 & $\mathrm{a}$ \\
\hline & $S$ & 50.13 & $\mathrm{~b}$ & 0.73 & $\mathrm{~b}$ \\
\hline & F-value & 5.08 & & 9.14 & \\
\hline & p-value & 0.044 & & 0.012 & \\
\hline \multirow{6}{*}{$125-148$} & $\mathrm{~T}$ & 104.46 & $\mathrm{a}$ & 2.26 & $\mathrm{a}$ \\
\hline & M & 107.10 & a & 2.42 & $\mathrm{a}$ \\
\hline & $\mathrm{F}$ & 91.26 & $\mathrm{~b}$ & 1.86 & $\mathrm{~b}$ \\
\hline & $S$ & 85.28 & $\mathrm{~b}$ & 1.87 & $\mathrm{~b}$ \\
\hline & F-value & 5.30 & & 5.06 & \\
\hline & p-value & 0.040 & & 0.044 & \\
\hline
\end{tabular}

In 2015, the third leaf season for the peach orchard, the harvest was performed in two picks: on 3 and 7 September, 149 and 153 DAFB, respectively. A late fruit drop occurred during the season modifying the initial crop load imposed. The ANCOVA revealed the significative effect of the number of fruit as the covariate variable for the yield ( $\mathrm{F}=63.26 ; p<0.001)$, fruit weight $(\mathrm{F}=19.98 ; p=0.001)$ and water productivity $(\mathrm{F}=30.98 ; p<0.001)$, whose values have been adjusted accordingly. The yield was similar among the treatments $\left(\sim 11.00 \mathrm{t} \mathrm{ha}^{-1}\right)$, while the fruit fresh weight was higher in $\mathrm{M}$ and $\mathrm{T}(166.9$ and $149.4 \mathrm{~g}$, respectively) than in F and S with values of 112.9 and $93.6 \mathrm{~g}$, respectively (Table 3). Water productivity was higher in $\mathrm{M}$ and $\mathrm{S}$ (average of $12.01 \mathrm{~kg} \mathrm{~m}^{-3}$ ) than in $\mathrm{T}$ and $\mathrm{F}$ with an average value of $6.93 \mathrm{~kg} \mathrm{~m}^{-3}$ (Table 3). No differences for the total soluble solid content was observed, recording an average value of about $18^{\circ}$ Brix. The percentage of fruit skin over color was higher in $\mathrm{M}(\sim 92.3 \%)$ than in the remaining treatments $(\sim 56.7 \%)$ while the flesh firmness was higher in $\mathrm{F}$, followed by $\mathrm{T}, \mathrm{S}$ and $\mathrm{M}$ with values of $3.7,3.0,2.8$, and $2.2 \mathrm{~kg} \mathrm{~cm}^{-2}$, respectively (Table 3). 
Table 3. Yield (Y), fruit fresh weight (FW), water productivity (WPi), sugar content (TSS) flesh firmness (FF) and fruit skin red overcolor, measured on the 4 treatments under investigation in 2015. Data were subjected to ANCOVA analysis, considering the number of fruits per tree as a covariate variable and were adjusted accordingly. For each variable, different letters indicate a statistical difference at $p \leq 0.05$.

\begin{tabular}{|c|c|c|c|c|c|c|c|c|c|c|}
\hline \multirow{2}{*}{$\begin{array}{c}\text { Treatment } \\
\mathrm{T}\end{array}$} & \multirow{2}{*}{$\begin{array}{c}\begin{array}{c}\mathbf{Y} \\
\text { (t ha-1) }^{-1}\end{array} \\
11.91\end{array}$} & \multicolumn{2}{|l|}{$\begin{array}{l}\text { FW } \\
\text { (g) }\end{array}$} & \multicolumn{2}{|c|}{$\begin{array}{c}\mathrm{WPi} \\
\left(\mathrm{kg} \mathrm{m}^{-3}\right)\end{array}$} & \multirow{2}{*}{$\begin{array}{c}\begin{array}{c}\text { TSS } \\
\left({ }^{\circ} \text { Brix }\right)\end{array} \\
18.07\end{array}$} & \multicolumn{2}{|c|}{$\begin{array}{c}F F \\
\left(\mathrm{~kg} \mathrm{~cm}^{-2}\right)\end{array}$} & \multicolumn{2}{|c|}{$\begin{array}{l}\mathrm{RC} \\
(\%)\end{array}$} \\
\hline & & 149.45 & $\mathrm{a}$ & 7.22 & $\mathrm{~b}$ & & 3.01 & $\mathrm{ab}$ & 58.33 & $\mathrm{~b}$ \\
\hline $\mathrm{M}$ & 10.82 & 166.94 & $\mathrm{a}$ & 12.23 & $\mathrm{a}$ & 17.34 & 2.18 & $\mathrm{~b}$ & 92.31 & $\mathrm{a}$ \\
\hline $\mathrm{F}$ & 10.96 & 112.91 & $\mathrm{~b}$ & 6.64 & $b$ & 18.73 & 3.70 & a & 55.00 & a \\
\hline$S$ & 10.44 & 93.61 & $\mathrm{~b}$ & 11.79 & $\mathrm{a}$ & 18.37 & 2.85 & $a b$ & 56.67 & $\mathrm{a}$ \\
\hline F-value & 0.70 & 17.59 & & 17.32 & & 2.02 & 5.12 & & 7.48 & \\
\hline p-value & 0.571 & $<0.001$ & & $<0.002$ & & 0.169 & 0.019 & & 0.005 & \\
\hline
\end{tabular}

\subsubsection{Season 2016}

During the pit hardening (57-107 DAFB) and the first part of fruit cell expansion stages (107-140 DAFB), no differences for fruit volume and AGR were recorded among the four treatments (Table 4; Figure 7). Afterwards (140-164 DAFB), the average fruit volume for the period was similar among the treatments, while the absolute growth rate was higher in $\mathrm{M}$ and $\mathrm{T}\left(5.89\right.$ and $5.16 \mathrm{~cm}^{3} \mathrm{day}^{-1}$, respectively) than in $S$ and $F$, with values of 4.63 and $4.31 \mathrm{~cm}^{3}$ day ${ }^{-1}$, respectively (Table 4). Starting from $150 \mathrm{DAFB}$, a divergent pattern for AGR was observed comparing T and $\mathrm{M}$ versus $\mathrm{F}$ and $\mathrm{S}$ : while in the former treatments AGR continued to increase, in the latter ones it decreased (Figure 7B). Close to the harvest, the fruit volume of $\mathrm{M}$ and $\mathrm{T}$ was higher than $\mathrm{F}$ and $\mathrm{S}$ (Figure 7A).

Table 4. Average fruit volume (V) and absolute growth rate (AGR) recorded on T, M, F and S treatments in different fruit growth stages, in 2016. Within each stage, a by-time repeated ANOVA was performed. For each variable, different letters indicate a statistical difference at $p \leq 0.05$.

\begin{tabular}{|c|c|c|c|}
\hline DAFB Range & Treatment & $\begin{array}{c}V \\
\left(\mathrm{~cm}^{3}\right)\end{array}$ & $\begin{array}{c}\text { AGR } \\
\left(\mathrm{cm}^{3} \mathrm{day}^{-1}\right)\end{array}$ \\
\hline \multirow{6}{*}{ 57-107 } & $\mathrm{T}$ & 35.99 & 0.73 \\
\hline & M & 33.19 & 0.59 \\
\hline & $\mathrm{F}$ & 35.45 & 0.73 \\
\hline & S & 35.11 & 0.69 \\
\hline & F-value & 0.44 & 2.59 \\
\hline & p-value & 0.731 & 0.149 \\
\hline \multirow{6}{*}{$107-140$} & $\mathrm{~T}$ & 77.81 & 1.94 \\
\hline & M & 73.17 & 1.64 \\
\hline & $\mathrm{F}$ & 80.54 & 2.02 \\
\hline & S & 73.17 & 1.77 \\
\hline & F-value & 1.85 & 1.67 \\
\hline & p-value & 0.239 & 0.271 \\
\hline \multirow{6}{*}{$140-164$} & $\mathrm{~T}$ & 190.61 & 5.16 \\
\hline & M & 180.13 & 5.89 \\
\hline & $\mathrm{F}$ & 182.93 & 4.63 \\
\hline & $S$ & 180.27 & 4.31 \\
\hline & F-value & 0.36 & 8.51 \\
\hline & p-value & 0.785 & 0.014 \\
\hline
\end{tabular}



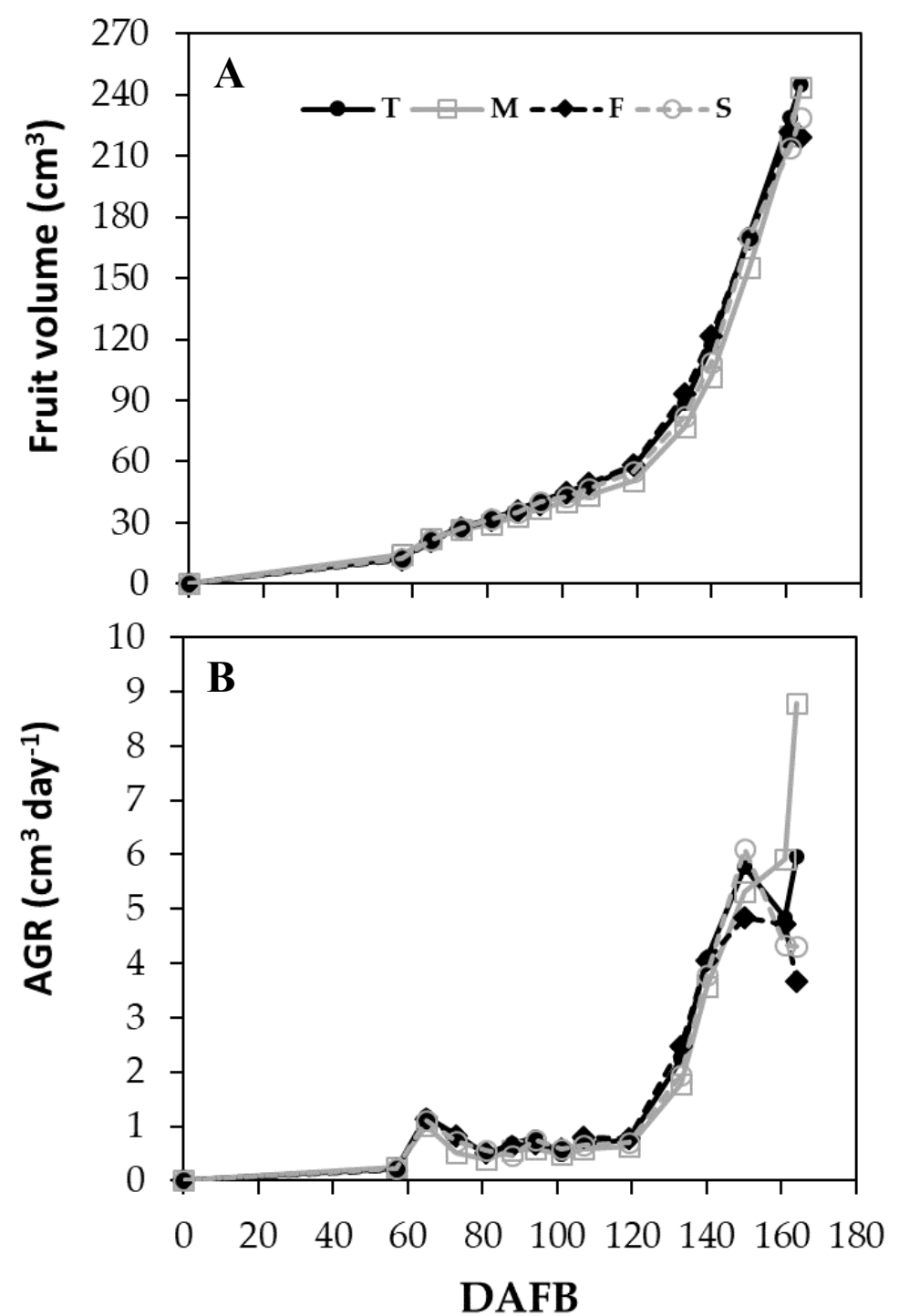

Figure 7. Fruit growth (A) and absolute growth rate (B) pattern recorded in 2016 on T, M, F and S treatments.

In 2016, the harvest occurred on 26 August (165 DAFB) with a single pick. Even in this season a late fruit drop affected the imposed crop load. The ANCOVA showed a significant effect of the number of fruits as a covariate variable for yield $(\mathrm{F}=126.95 ; p<0.001)$ and $\mathrm{WPi}(\mathrm{F}=76.84 ; p<0.001)$, whose values have been adjusted accordingly. $\mathrm{Y}$ was similar for the four treatments, with values ranging from $16.78 \mathrm{t} \mathrm{ha}^{-1}(\mathrm{M})$ to $13.56 \mathrm{t} \mathrm{ha}^{-1}(\mathrm{~F})$. Fruit fresh weight was higher in $\mathrm{M}(256.65 \mathrm{~g})$ than in $\mathrm{T}(234.46 \mathrm{~g})$ and the lowest values were observed in S and F with FW of 216.92 and $211.65 \mathrm{~g}$, respectively (Table 5). The highest WPi was recorded in $\mathrm{M}\left(16.2 \mathrm{~kg} \mathrm{~m}^{-3}\right)$, followed by $\mathrm{S}\left(14.03 \mathrm{~kg} \mathrm{~m}^{-3}\right), \mathrm{T}\left(8.38 \mathrm{~kg} \mathrm{~m}^{-3}\right)$ and $\mathrm{F}$ with WPi of $7.45 \mathrm{~kg} \mathrm{~m}^{-3}$ (Table 5). No difference in terms of sugar content, flesh firmness and percentage of red overcolor was observed among the treatments (Table 5). 
Table 5. Yield (Y), fruit fresh weight (FW), water productivity (WPi), sugar content (TSS) flesh firmness (FF) and fruit skin red overcolor, measured on the 4 treatments under investigation in 2016. Data were subjected to ANCOVA analysis, considering the number of fruits per tree as a covariate variable and were adjusted accordingly. For each variable, different letters indicate a statistical difference at $p \leq 0.05$.

\begin{tabular}{|c|c|c|c|c|c|c|c|c|}
\hline \multirow{2}{*}{$\begin{array}{c}\text { Treatment } \\
\mathrm{T}\end{array}$} & \multirow{2}{*}{$\begin{array}{c}\mathbf{Y} \\
\text { (t ha-1) }^{-1}\end{array}$} & \multicolumn{2}{|l|}{$\begin{array}{l}\text { FW } \\
(\mathrm{g})\end{array}$} & \multicolumn{2}{|c|}{$\begin{array}{c}\text { WPi } \\
\left(\mathrm{kg} \mathrm{m}^{-3}\right)\end{array}$} & \multirow{2}{*}{$\begin{array}{c}\begin{array}{c}\text { TSS } \\
\left({ }^{\circ} \text { Brix }\right)\end{array} \\
14.16\end{array}$} & \multirow{2}{*}{$\begin{array}{c}\begin{array}{c}\mathrm{FF} \\
\left(\mathrm{kg} \mathrm{cm}^{-2}\right)\end{array} \\
4.58\end{array}$} & \multirow{2}{*}{$\begin{array}{c}\begin{array}{c}\text { RC } \\
(\%)\end{array} \\
84.07\end{array}$} \\
\hline & & 234.46 & $\mathrm{ab}$ & 8.39 & $\mathrm{~b}$ & & & \\
\hline $\mathrm{M}$ & 16.78 & 256.65 & $\mathrm{a}$ & 16.22 & $\mathrm{a}$ & 13.75 & 4.96 & 93.89 \\
\hline F & 13.56 & 211.65 & $\mathrm{~b}$ & 7.45 & $\mathrm{~b}$ & 14.13 & 4.26 & 93.33 \\
\hline$S$ & 14.35 & 216.92 & $\mathrm{~b}$ & 14.03 & $\mathrm{a}$ & 13.78 & 3.58 & 84.63 \\
\hline F-value & 0.19 & 3.49 & & 4.56 & & 0.73 & 0.76 & 2.38 \\
\hline p-value & 0.899 & 0.052 & & 0.026 & & 0.553 & 0.539 & 0.125 \\
\hline
\end{tabular}

\section{Discussion}

The thermic pattern during the two years of study was quite similar and in line with the average of the site while year 2015 was less rainy than 2016 (Figure 1). The similar chemical-physical conditions of the soil recorded at the beginning of the trial suggested that the starting point for the four treatments was the same (Table 1). At the end of 2016, the different floor and water managements affected the soil chemical features (Table 1). S, subjected to water restriction and tillage, showed a decrease in TOC and assimilable P. As observed in other studies, under semi-arid conditions the high temperature and evapo-transpirative demand of the environment, jointly with the low soil moisture lasting for long time during the year, may have increased the mineralization processes, reducing the already low organic carbon in the soil $[10,42,43]$. An additional, related consequence could have been the reduction in $\mathrm{P}$ in its assimilable form in the tilled treatment subjected to water shortage [44]. A decrease in P in its assimilable form was observed in an evergreen forest, in the Mediterranean area, subjected to drought stress [45]. M, experiencing the same water supply of $S$, did not show a decrease in TOC suggesting the positive role of artificial, reflective mulching in preventing organic matter over degradation (Table 1). The use of organic mulching (F) did not affect TOC, while it was not possible to verify if the increase in $\mathrm{P}$ occurring in this treatment was given by the floor management per se or to the increased amount of P supplied as fertilizer to feed the service crop (Table 1). Artificial reflective mulching reduced soil evaporation behaving as a physical barrier against the water loss but also reducing solar radiation absorption by the soil and the wind speed at the surface [46]. Even when receiving about $50 \%$ less water than the control (T), M maintained SWC higher than T for most of the irrigation season in both years (Figure 3). These preliminary results confirmed what was observed in other studies on rain-fed peach orchards where mulching with plastic film reduced water loss of about $15 \%$ in comparison with tilled soil [14]. The flattening technique (F) ameliorated SWC conditions in the rainier year (2016) till the end of July. Afterward, its SWC dropped faster than T after irrigation, in both the years (Figure 3). This rapid water depletion might have been attributable to the disruption of the natural mulching and to the onset of relevant soil cracking occurring in clay soils, low in organic matter [47]. August was characterized by a general water limitation caused by watershed restriction usually occurring in this area (water demand for crop and for civil use increases in this period). Under this stressful condition, M continued to maintain SWC higher than the remaining treatments (Figure 3); only in a few cases its soil water content dropped below the IT, assuring an adequate soil moisture for all the season long $[13,15]$. When the soil evaporation was not contrasted, the reduction in water supply (S), produced a progressive consumption of the readily available water with values of SWC very low and below the IT (Figure 3).

Soil and water management strategies affected leaf functionality and water relations in peach trees. In both the years, when water supply was not yet differentiated among the four treatments and SWC was within the readily available water range (Figure 3), T, M, F and S behaved similarly (Figures 4 and 5) for carbon assimilation $(\Sigma \mathrm{Pn})$, water transpiration $(\Sigma \operatorname{Tr})$ and plant water status, expressed as water 
stress integral $\left(\mathrm{S}_{\Psi}\right)$. Reflective mulching, preventing the excessive soil evaporation and increasing the diffuse light, maintained the pedo-climatic conditions favorable to photosynthetic activity of leaves $[13,14]$ for the entire vegetative-reproductive season in the two years of study (Figures $4 \mathrm{~A}$ and $5 \mathrm{~A}$ ). Excluding the measure performed in 2016 at $124 \mathrm{DAFB}$ (12 July), $\Sigma \mathrm{Pn}, \Sigma \operatorname{Tr}$ and $\mathrm{S}_{\Psi}$ in M were similar, and in some cases higher than $T$ receiving double the amount of water (Figures 4 and 5). When water shortage was associated to tillage $(\mathrm{S})$, tree water status $\left(\mathrm{S}_{\Psi}\right)$ was affected and net photosynthesis was subjected to stomatal limitation (reduction in average gs and $\Sigma T r$ ) and probably to non-stomatal limitation as well (Figures 4 and 5). Previous research in pear, apple, peach and grapevine suggested that stomatal closure could affect leaf thermoregulation inducing the increase in leaf temperature and raising the activity of photorespiration [48-50]. This process is a photoprotective strategy for the plant, but it means a loss of carbon in terms of biomass accumulation [51-53]. The use of natural mulching associated with full irrigation (F) did not affect leaf functionality ( $\Sigma \mathrm{Pn}$ and $\Sigma \mathrm{Tr}$ ) in comparison with $\mathrm{T}$ till the end of July, in both years (Figures 4 and 5). This suggested the absence of such competition between the main and the service crop and the positive effect of the flattening technique in controlling weeds. This positive effect was already observed in vegetable crops [54,55]. In August, when the flattened crop was disrupted and the soil cracking caused a rapid water depletion (Figure 5, 163 DAFB), $\mathrm{S}_{\Psi}, \Sigma \mathrm{Pn}$ and $\Sigma \operatorname{Tr}$ values in $\mathrm{F}$ were the lowest of the four treatments. From a leaf functioning point of view the use of the flattening technique for all of the dry season appeared to be detrimental under particular pedoclimatic conditions such as hot summer, clay and poor of organic matter soils.

The differences among the treatments appeared more evident when high temperature and VPD were associated with soil moisture limitation. The comparison between the days 86 and 87 DAFB of year 2015 revealed that SWC did not change markedly within each treatment as well as $S_{\Psi}$ (Figure 4C). However, at $87 \mathrm{DAFB}$, the environment was more water demanding than the previous day: the average $\mathrm{T}_{\text {air }}$ and VPD passed from 36.4 to $37.5^{\circ} \mathrm{C}$ and from 3.5 to $4.5 \mathrm{kPa}$, respectively. As a consequence, soil with an adequate SWC allowed leaves to maintain the stomata opened, increasing $\Sigma \operatorname{Tr}$ and $\Sigma \mathrm{Pn}$. On the other hand, S, having a low SWC, reduced gs and leaf transpiration [56], thus carbon assimilation (Figure 4A). Trees, being in the middle of the Soil Plant Air Continuum (S.P.A.C.) were strongly influenced by the status of rhizosphere and air. The comparison between $F$ and $S$ at 86,87 and 88 DAFB revealed that, even if the two treatments had the same $S_{\Psi}$ and midday stem water potential, $S$ showed a cumulative net photosynthesis and leaf transpiration lower than F (Figure 4). The same behavior was observed in 2016, comparing $M$ and S at 124 DAFB and F and S at 135 DAFB. This late ripening peach cultivar seemed to have a "pessimistic" (also called conservative or near iso-hydric) behavior. At low soil water content and high vapor pressure deficit, $\mathrm{S}$ sustained its stem water potential, at the same level of $\mathrm{F}$, above a safe threshold to prevent embolism [57,58]. This defense strategy was at the expense of $\mathrm{CO}_{2}$ fixation since it was regulated by stomatal closure [59,60]. These findings are in contrast with those described by Xiloyannis et al. (1980) on another late ripening peach cultivar considered aniso-hydric [61], suggesting the needing to deepen this issue.

During the first year of study, the pattern of fruit growth of the four treatments was similar till the end of fruit cell division stage (38-77 DAFB); however, M and S, receiving less water, showed an average absolute growth rate lower than $\mathrm{T}$ and $\mathrm{F}$ (Table 2). This difference was completely recovered in $\mathrm{M}$ during the pit hardening stage (77-105 DAFB), while S continued to have an average AGR lower than the remaining treatments (Table 2). Passing from pit hardening to the fruit cell expansion stage (105-125 DAFB), peach fruit became more water and carbon demanding [62]. Water shortage, jointly with the reduction in net photosynthesis, led to fruit growth limitation. As revealed by the average $\mathrm{V}$ and AGR in the period 105-125 DAFB (Table 2; Figure 6), the reduced AGR initially observed in S during the pit hardening (77-105 DAFB) resulted in fruit size lower than the remaining treatments (Table 2). In August, during the last part of fruit cell expansion and close to the harvest (125-148 DAFB), fruit growth was limited even in F, suggesting that the rapid water depletion occurring in this period affected fruit volume and growth rate (Table 2, Figure 6). All the advantage of $\mathrm{F}$ on $\mathrm{S}$ was lost, and, at the end of the season, the two treatments showed the smallest fruits (Figure 6, Table 3). The 
same behavior was observed in 2016. The rainier season alleviated the effect of water shortage and till 140 DAFB (first part of fruit cell expansion) no differences were recorded among the treatments for fruit volume and AGR (Table 4, Figure 7). During the last part of fruit cell expansion (140-164 DAFB), even in this season, F and S showed the lowest average AGR (Table 4), fruit volume (Figure 6) and fruit size (Table 5).

Fruit yield was generally low considering that Calred is a late ripening cultivar. However, it should be taken into account that this cultivar was subjected to a late fruit drop in both the years and that, probably, trees were not at a fully mature productive status, as in 2015 and 2016, they were at third and fourth leaf, respectively. The different orchard floor management and water supply did not affect yield, but the fruit size with biggest fruit picked on $\mathrm{T}$ and $\mathrm{M}$ (Tables 3 and 5). Water productivity of $\mathrm{M}$ was about 70 and $90 \%$ higher than T suggesting that the use of artificial reflective mulching could be considered a water friendly strategy in rainfed [14] as well as in irrigated peach orchards (Tables 3 and 5). Although in 2015 peaches seemed to ripe earlier in $\mathrm{M}$ in comparison with the remaining treatments (Table 3), fruit quality (TSS, FF and RC) was generally not affected by the different managements (Tables 3 and 4 ).

\section{Conclusions}

Under semi-arid conditions and where water supply is limited, the choice of an appropriate orchard floor management could be of pivotal importance for getting the peach production both economic and environment-friendly. Even receiving about $50 \%$ of the regular irrigation, reusable reflective mulching reduced water loss and soil carbon over mineralization, not affecting (sometimes increasing) net carbon assimilation, yield, and fruit size. As a consequence, water productivity was drastically increased. These first results suggested that the reflective mulching strategy could be considered to be water and soil "friendly". This management technique is firstly described and explored on a peach orchard, thus the studies on the development and the use of alternative material for mulching should be explored. The flattening technique as mulching strategy should be refined for the final part of the irrigation season, especially in those hot and dry areas with clay soils, low in organic matter, thus predisposed to cracking.

Supplementary Materials: The following are available online at http://www.mdpi.com/2076-3417/10/22/8135/s1, Table S1: Anova results for Cumulative leaf net photosynthesis $(\Sigma \mathrm{Pn})$, transpiration $(\Sigma \operatorname{Tr})$ and water stress integral (SY) calculated in each day of measurement in 2015 and 2016. For each variable, within the same date the asterisk indicates $p \leq 0.05$.

Author Contributions: Conceptualization, P.L.; data curation, L.G., L.M., L.T. and P.C.; formal analysis, L.G. and P.C.; investigation, L.G., L.T. and P.C.; methodology, P.L. and P.C.; supervision, P.L.; validation, P.L. and L.G.; writing — original draft, P.L. and L.M.; Writing—review and editing, P.L., L.G. and L.M. All authors have read and agreed to the published version of the manuscript.

Funding: This research received no external funding.

Acknowledgments: The authors would like to thank Di Gennaro D. and Amendolagine A.M. for their contribution in data collecting, and Introna P. and Volpicella M. for their valuable operative effort in conducting the orchard.

Conflicts of Interest: The authors declare no conflict of interest.

\section{References}

1. Morandi, B.; Manfrini, L.; Zibordi, M.; Corelli-Grappadelli, L.; Losciale, P. From fruit anatomical features to fruit growth strategy: Is there a relationship? Acta Hortic. 2016, 1130, 185-191. [CrossRef]

2. Tous, J.; Ferguson, L. Mediterranean fruits. In Progress in New Crops; Janick, J., Ed.; ASHS Press: Arlington, VA, USA, 1996; pp. 416-430.

3. Charles, M.; Corollaro, M.L.; Manfrini, L.; Endrizzi, I.; Aprea, E.; Zanella, A.; Corelli Grappadelli, L.; Gasperi, F. Application of a sensory-instrumental tool to study apple texture characteristics shaped by altitude and time of harvest. J. Sci. Food Agric. 2018, 98, 1095-1104. [CrossRef] [PubMed] 
4. Corollaro, M.L.; Manfrini, L.; Endrizzi, I.; Aprea, E.; Demattè, M.L.; Charles, M.; Bergamaschi, M.; Biasioli, F.; Zibordi, M.; Corelli Grappadelli, L.; et al. The effect of two orchard light management practices on the sensory quality of apple: Fruit thinning by shading or photo-selective nets. J. Hort. Sci. Biotech. 2015, 90, 99-107. [CrossRef]

5. Demestihas, C.; Plénet, D.; Génard, M.; Raynal, C.; Lescourret, F. Ecosystem services in orchards. A review. Agron. Sustain. Dev. 2017. [CrossRef]

6. Morandi, B.; Manfrini, L.; Losciale, P.; Zibordi, M.; Corelli Grappadelli, L. The positive effect of skin transpiration in peach fruit growth. J. Plant. Phys. 2010, 167, 1033-1037. [CrossRef]

7. Lopez, G.; Boini, A.; Manfrini, L.; Torres-Ruiz, J.M.; Pierpaoli, E.; Zibordi, M.; Losciale, P.; Morandi, B.; Corelli-Grappadelli, L. Effect of shading and water stress on light interception, physiology and yield of apple trees. Agr. Water Manag. 2018, 210, 140-148. [CrossRef]

8. Perulli, G.D.; Bresilla, K.; Manfrini, L.; Boini, A.; Sorrenti, G.; Corelli Grappadelli, L.; Morandi, B. Beneficial effect of secondary treated wastewater irrigation on nectarine tree physiology. Agr. Water Manag. 2019, 221, 120-130. [CrossRef]

9. González-Hidalgo, J.C.; Pena-Monné, J.L.; de Luis, M. A review of daily soil erosion in Western Mediterranean areas. Catena 2007, 71, 193-199. [CrossRef]

10. Ventrella, D.; Stellacci, A.M.; Castrignanò, A.; Charfeddine, M.; Castellini, M. Effects of crop residue management on winter durum wheat productivity in a long term experiment in Southern Italy. Eur. J. Agron. 2016, 77, 188-198. [CrossRef]

11. Vinyes, E.; Asin, L.; Alegre, S.; Muñoz, P.; Boschmonart, J.; Gasol, C.M. Life Cycle Assessment of apple and peach production, distribution and consumption in Mediterranean fruit sector. J. Clean. Prod. 2017, 149, 313-320. [CrossRef]

12. Water for Sustainable Food and Agriculture FAO Report 2017. Available online: http://www.fao.org/3/ai7959e.pdf (accessed on 6 November 2020).

13. Yaghi, T.; Arslan, A.; Naoum, F. Cucumber (Cucumis sativus L.) water use efficiency (WUE) under plastic mulch and drip irrigation. Agric. Water Manag. 2013, 128, 149-157. [CrossRef]

14. Wang, C.; Wang, H.; Zhao, X.; Chen, B.; Wang, F. Mulching affects photosynthetic and chlorophyll a fluorescence characteristics during stage III of peach fruit growth on the rain-fed semiarid Loess Plateau of China. Sci. Hortic. 2015, 194, 246-254. [CrossRef]

15. Campi, P.; Gaeta, L.; Mastrorilli, M.; Losciale, P. Innovative Soil Management and Micro-Climate Modulation for Saving Water in Peach Orchards. Front. Plant Sci. 2020, 11. [CrossRef] [PubMed]

16. Fan, J.; Gao, Y.; Wang, Q.; Sukhdev, S.M.; Li, Y. Mulching effects on water storage in soil and its depletion by alfalfa in the Loess Plateau of northwestern China. Agric. Water Manag. 2014, 138, 10-16.

17. Diacono, M.; Fiore, A.; Farina, R.; Canali, S.; Di Bene, C.; Testani, E.; Montemurro, F. Combined Agro-ecological Strategies for Adaptation of Organic Horticultural Systems to Climate Change in Mediterranean Environment. Ital. J. Agron. 2016, 11, 85-91. [CrossRef]

18. Antichi, D.; Sbrana, M.; Martelloni, L.; Abou Chehade, L.; Fontanelli, M.; Raffaelli, M.; Mazzoncini, M.; Peruzzi, A.; Frasconi, C. Agronomic Performances of Organic Field Vegetables Managed with Conservation Agriculture Techniques: A Study from Central Italy. Agronomy 2019, 9, 810. [CrossRef]

19. Tosti, G.; Benincasa, P.; Farneselli, M.; Guiducci, M.; Onofri, A.; Tei, F. Processing Tomato-Durum Wheat Rotation under Integrated, Organic and Mulch-Based No-Tillage Organic Systems: Yield, N Balance and N Loss. Agronomy 2019, 9, 718. [CrossRef]

20. Salomé, C.; Coll, P.; Lardo, E.; Metay, A.; Villenave, C.; Marsden, C.; Blanchart, E.; Hinsinger, P.; Le Cadre, E. The soil quality concept as a framework to assess management practices in vulnerable agroecosystems: A case study in Mediterranean vineyards. Ecol. Indic. 2016, 61, 456-465. [CrossRef]

21. Tarricone, L.; Debiase, G.; Masi, G.; Gentilesco, G.; Montemurro, F. Cover Crops Affect Performance of Organic Scarlotta Seedless Table Grapes Under Plastic Film Covering in Southern Italy. Agronomy 2020, 10, 550. [CrossRef]

22. Almagro, M.; Garcia-Franco, N.; Martínez-Mena, M. The potential of reducing tillage frequency and incorporating plant residues as a strategy for climate change mitigation in semiarid Mediterranean agroecosystems. Agric. Ecosyst. Environ. 2017, 246, 210-220. [CrossRef]

23. Montanaro, G.; Dichio, B.; Briccoli Bati, C.; Xiloyannis, C. Soil management affects carbon dynamics and yield in a Mediterranean peach orchard. Agric. Ecosyst. Environ. 2012, 161, 46-54. [CrossRef] 
24. Losciale, P.; Manfrini, L.; Morandi, B.; Pierpaoli, E.; Zibordi, M.; Stellacci, A.M.; Salvati, L.; Corelli Grappadelli, L. A multivariate approach for assessing leaf photoassimilation performance using the IPL index. Physiol. Plant. 2015, 154, 609-620. [CrossRef] [PubMed]

25. Manfrini, L.; Pierpaoli, E.; Zibordi, M.; Morandi, B.; Muzzi, E.; Losciale, P.; Corelli Grappadelli, L. Monitoring strategies for precise production of high-quality fruit and yield in apple in Emilia-Romagna. Chem. Eng. Trans. 2015, 44, 301-306.

26. Manfrini, L.; Corelli Grappadelli, L.; Morandi, B.; Losciale, P.; Taylor, J.A. Innovative approaches to orchard management: Assessing the variability in yield and maturity in a 'Gala' apple orchard using a simple management unit modeling approach. Eur. J. Hortic. Sci. 2020, 84, 1-8. [CrossRef]

27. Jordan, M.O.; Vercambre, G.; Gomez, L.; Pagès, L. The early spring N uptake of young peach trees (Prunus persica) is affected by past and current fertilizations and levels of $C$ and $N$ stores. Tree Physiol. 2014, 34, 61-72. [CrossRef]

28. Morandi, B.; Boselli, F.; Boini, A.; Manfrini, L.; Corelli Grappadelli, L. The fruit as a potential indicator of plant water status in apple. Acta Hortic. 2017, 1150, 83-90. [CrossRef]

29. Tozzi, F.; van Hooijdonk, B.M.; Tustin, D.S.; Corelli Grappadelli, L.; Morandi, B.; Losciale, P.; Manfrini, L. Photosynthetic Performance and Vegetative Growth in a New Red Leaf Pear: Comparison of Scion Genotypes Using a Complex, Grafted-Plant System. Front. Plant Sci. 2018. [CrossRef]

30. Ham, J.M.; Kluitenberg, G.J.; Lamont, W.J. Optical properties of plastic mulches affect the field temperature regime. J. Amer. Soc. Hort. Sci. 1993, 118, 188-193. [CrossRef]

31. Zheng, W.; Wen, M.; Zhao, Z.; Liu, J.; Wang, Z.; Zhai, B.; Li, Z. Black plastic mulch combined with summer cover crop increases the yield and water use efficiency of apple tree on the rainfed Loess Plateau. PLoS ONE 2017, 12. [CrossRef]

32. Okie, W.R. Handbook of Peach and Nectarine Varieties—Agriculture Handbook number 714; U.S. Department of Agriculture; Agricultural Research Service: Washington, DC, USA, 1998; p. 42.

33. Campi, P.; Palumbo, A.D.; Mastrorilli, M. Evapotranspiration estimation of crops protected by windbreak in a Mediterranean region. Agr. Water Manag. 2012, 104, 153-162. [CrossRef]

34. U.S. Department of Agriculture; Soil Conservation Service. Soil Taxonomy: A Basic System of Soil Classification for Making and Interpreting Soil Surveys; Soil Survey Staff, 1975 Department of Agriculture Handbook 436; U.S. Government Printing Office: Washington, DC, USA, 1975.

35. Allen, R.G.; Pereira, L.S.; Raes, D.; Smith, M. Crop Evapotranspiration. Guide-Lines for Computing Crop Water Requirements. FAO Irrigation and Drainage Paper No. 56; FAO-Food and Agriculture Organization of the United Nations: Rome, Italy, 1998.

36. Campi, P.; Navarro, A.; Palumbo, A.D.; Modugno, F.; Vitti, C.; Mastrorilli, M. Energy of biomass sorghum irrigated with reclaimed wastewaters. Eur. J. Agron. 2016, 76, 176-185. [CrossRef]

37. Naor, A.; Klein, I.; Doron, I. Stem water potential and apple size. J. Am. Soc. Hortic. Sci. 1995, 120, 577-582. [CrossRef]

38. Losciale, P.; Chow, W.S.; Corelli Grappadelli, L. Modulating the light environment with the peach "asymmetric orchard": Effects on gas exchange performances, photoprotection, and photoinhibition. J. Exp. Bot. 2010, 61, 1177-1192. [CrossRef] [PubMed]

39. Myers, B.J. Water stress integral. A link between short-term stress and long-term growth. Tree Physiol. 1988, 4, 315-323. [CrossRef]

40. Fernández, M.D.; Hueso, J.J.; Cuevas, J. Water stress integral for successful modification of flowering dates in 'Algerie' loquat. Irrig. Sci. 2010, 28, 127-134. [CrossRef]

41. Fernández, J.E.; Alcon, F.; Diaz-Espejo, A.; Hernandez-Santana, V.; Cuevas, M.V. Water use indicators and economic analysis for on-farm irrigation decision: A case study of a super high density olive tree orchard. Agr. Water Manag. 2020, 237. [CrossRef]

42. Davidson, E.A.; Janssens, I.A. Temperature sensitivity of soil carbon decomposition and feedbacks to climate change. Nature 2006, 440, 165-173. [CrossRef]

43. Abdelhafez, A.A.; Abbas, M.H.H.; Attia, T.M.S.; El Bably, W.; Mahrous, S.E. Mineralization of organic carbon and nitrogen in semi-arid soils under organic and inorganic fertilization. Environ. Technol. Innov. 2018, 9, 243-253. [CrossRef]

44. Cramer, M.D.; Hawkins, H.J.; Verboom, G.A. The importance of nutritional regulation of plant water flux. Oecologia 2009, 161, 15-24. [CrossRef] 
45. Sardans, J.; Peñuelas, J. Increasing drought decreases phosphorus availability in an evergreen Mediterranean forest. Plant. Soil 2004, 267, 367-377. [CrossRef]

46. Eberbach, P.L.; Humphreys, E.; Kukal, S.S. The effect of rice straw mulch on evapotranspiration, transpiration and soil evaporation of irrigated wheat in Punjab, India. Agric. Water Manag. 2011, 98, 1847-1855.

47. Ritchie, J.T.; Adams, J.E. Field measurement of evaporation from soil shrinkage cracks. Soil Sci. Soc. Am. Proc. 1974, 38, 131-134. [CrossRef]

48. Flexas, J.; Bota, J.; Escalona, J.M.; Sampol, B.; Medrano, H. Effects of drought on photosynthesis in grapevines under field conditions: An evaluation of stomatal and mesophyll limitations. Funct. Plant. Biol. 2002, 29, 461-471. [CrossRef]

49. Losciale, P.; Zibordi, M.; Manfrini, L.; Morandi, B.; Bastias, R.M.; Corelli Grappadelli, L. Light management and photoinactivation under drought stress in peach. Acta Hortic. 2011, 922, 341-347. [CrossRef]

50. Losciale, P.; Manfrini, L.; Morandi, B.; Novak, B.; Pierpaoli, E.; Zibordi, M.; Corelli Grappadelli, L.; Anconelli, S.; Galli, F. Water restriction effect on pear rootstocks: Photoprotective processes and the possible role of photorespiration in limiting carbon assimilation. Acta Hortic. 2014, 1058, 237-244. [CrossRef]

51. Galmés, J.; Abadia, A.; Cifre, J.; Medrano, H.; Flexas, J. Photoprotection processes under water stress and recovery in Mediterranean plants with different growth forms and leaf habits. Physiol. Plant. 2007, 130, 495-510. [CrossRef]

52. Foyer, C.H.; Harbinson, J. Oxygen metabolism and the regulation of photosynthetic electron transport. In Causes of Photooxidative Stress and Amelioration of Defence Systems in Plants; Foyer, C.H., Mullineaux, P.M., Eds.; CRC Press: Boca Raton, FL, USA, 1994; pp. 1-42.

53. Osmond, C.B. Photorespiration and photoinhibition: Some implication for the energetics of photosynthesis. Biochim. Et Biophys. Acta 1981, 639, 77-98. [CrossRef]

54. Canali, S.; Campanelli, G.; Ciaccia, C.; Leteo, F.; Testani, E.; Montemurro, F. Conservation tillage strategy based on the roller crimpertechnology for weed control in Mediterranean vegetable organic cropping systems. Eur. J. Agron. 2013, 50, 11-18. [CrossRef]

55. Ciaccia, C.; Testani, E.; Campanelli, G.; Sestili, S.; Leteo, F.; Tittarelli, F.; Riva, F.; Canali, S.; Trinchera, A. Ecological service providing crops effect on melon-weed competition and allelopathic interactions. Org. Agr. 2015, 5, 199-207. [CrossRef]

56. Jarvis, P.G. The interpretation of the variations in leaf water potential and stomatal conductance found in canopies in the field. Philos. Trans. R. Soc. Lond. B 1976, 273, 593-610.

57. Lauri, P.É.; Barigah, T.S.; Lopez, G.; Martinez, S.; Losciale, P.; Zibordi, M.; Manfrini, L.; Corelli Grappadelli, L.; Costes, E.; Regnard, J.L. Genetic variability and phenotypic plasticity of apple morphological responses to soil water restriction in relation with leaf functions and stem xylem conductivity. Trees 2016, 30, 1893-1908. [CrossRef]

58. Tardieu, F.; Simonneau, T. Variability among species of stomatal control under fluctuating soil water status and evaporative demand: Modelling isohydric and anisohydric behaviours. J. Exp. Bot. 1998, 49, 419-432. [CrossRef]

59. Gollan, T.; Turner, N.C.; Schulze, E.D. The responses of stomata and leaf gas exchange to vapour pressure deficits and soil water content. Oecologia 1985, 65, 356-362. [CrossRef] [PubMed]

60. Socías, X.; Correia, M.J.; Chaves, M.; Medrano, H. The role of abscisic acid and water relations in drought responses of subterranean clover. J. Exp. Bot. 1997, 48, 1281-1288. [CrossRef]

61. Xiloyannis, C.; Uriu, K.; Martin, G.C. Seasonal and diurnal variations in absicic acid, water potential, and diffusive resistance in leaves from irrigated and non-irrigated peach trees. J. Am. Soc. Hortic. Sci. 1980, 105, 412-415.

62. Morandi, B.; Rieger, M.W.; Corelli Grappadelli, L. Vascular flows and transpiration affect peach (Prunus Persica Batsch.) fruit daily growth. J. Exp. Bot. 2007, 58, 3941-3947. [CrossRef]

Publisher's Note: MDPI stays neutral with regard to jurisdictional claims in published maps and institutional affiliations. 